\title{
5. Pacific Islands' debt: financing post-COVID-19 recovery amid precarious sustainability
}

\author{
Roland Rajah and Alexandre Dayant ${ }^{1}$
}

\section{INTRODUCTION}

The small island states of the Pacific region face uniquely difficult financing challenges, even during normal times. The region's extreme geography poses intrinsic barriers to economic growth and development while subjecting the Pacific to large and frequent negative shocks. Debt sustainability is consequently a perennial concern and most Pacific countries are heavily reliant on official development partners to meet their financing needs in a sustainable way.

Today, the most pressing challenge for the Pacific and its development partners is responding to the economic crisis unleashed by the COVID-19 pandemic. With growth collapsing and debt levels already elevated, there is widespread concern that the developing world writ large faces a looming debt crisis (Bulow et al. 2020). Much international attention is consequently focused on the need for coordinating substantial debt relief. In the Pacific, most economies were already at an elevated risk of debt distress prior to the pandemic, according to the International Monetary Fund (IMF) and the World Bank. This raises important questions for the Pacific and its development partners. Does the Pacific face an impending debt crisis? What should the financing priorities be for enabling the region's recovery? And how can the scale of external support needed realistically be mobilized given the Pacific's development partners are also dealing with economic crises at home? We take up these key questions in this chapter.

The spread of the novel coronavirus which began in the Chinese city of Wuhan in late 2019 has led to the worst global economic downturn since at the least the Great Depression. At the time of writing, most Pacific economies have avoided major outbreaks of the disease itself. The major exception is Papua New Guinea (PNG) - the largest country in the region - which after initial success in suppressing the virus experienced a surge in new infections starting in early 2021. The health outlook in PNG remains uncertain. Yet, even though the rest of the Pacific has fared among the best in the world in limiting the spread of the virus, the grim reality is that the economic devastation is still likely to be among the most severe-especially for several Pacific economies that are heavily dependent on international tourism.

In response to the COVID-19 shock, there is an important need in all countries for large-scale fiscal expansion aimed at keeping economies, and societies, afloat through the depths of the crisis and providing enough stimulus to enable the economic recovery thereafter. Yet most Pacific countries have little ability to finance such economic largesse-being aid-dependent, 
having little to no access to global capital markets, and with their balance of payments also under pressure as key external income sources (tourism, remittances, commodities) have fallen off, if not collapsed. Official development partners have responded with various assistance measures. However, this has largely been sufficient only to plug the immediate fiscal and balance of payments financing gaps caused by drops in government revenue and external income, rather than enabling the large-scale countercyclical stimulus needed. As a result, the economic damage from the crisis for many Pacific economies is likely to be deep and long-lasting. With the risks of debt distress generally considered elevated before the pandemic, this raises critical questions about the future of debt sustainability in the Pacific. With this context in mind, this chapter seeks to make three main contributions.

First, we provide a preliminary analysis of the potential debt sustainability implications of the COVID-19 crisis in the Pacific. We review recent debt sustainability analyses produced by the IMF and provide our own quantitative analysis focused on the outlook for public sector solvency in the Pacific. We focus particularly on four countries-Fiji, PNG, Samoa, and Tonga-which arguably face the most uncertain debt outlooks as a result of the pandemic.

Next, we consider what it will take for the Pacific to recover from the pandemic. We argue that given the scale of the shock, a well-designed, large-scale recovery package financed by development partners, focused on public investment and implemented over several years would be likely to have large economic benefits. We use fiscal multipliers to estimate that the Pacific will require a "recovery package" of $\$ 2.3$ billion- $\$ 3.5$ billion (constant 2019 US dollars) in additional external financing over the coming years in order to recover fully from the pandemic.

Finally, a key question is how this can be financed. In an unconstrained world, a dramatic increase in grant aid would be the most beneficial form of financing, especially in response to what is a once-in-a-century exogenous shock for which concerns about moral hazard are largely irrelevant. Yet, signs of a major increase in external aid in response to the pandemic are yet to materialize, with key bilateral partners focusing their resources on combating recessions at home. We therefore consider the debt sustainability implications if the recovery were to be financed with semi-concessional loans from development partners. Our analysis suggests that this is a viable option.

\section{COVID-19 AND THE PACIFIC}

The small island states of the Pacific are some of the most remote countries in the world. Remoteness is generally seen as a major economic impediment for the region. But during the current crisis the Pacific was able to take advantage of its physical isolation to avoid major outbreaks of the COVID-19 disease - notably through early border closures, with several governments imposing travel restrictions as early as January 2020.

Overall, the region has been among the most successful in the world in containing the domestic spread of COVID-19. At the time of writing, most Pacific countries had not had a single case of the virus. PNG, the largest economy in the region by far, is the major exception. After initial success in suppressing the virus, PNG experienced a surge in new cases starting in early 2021 and, at the time of writing, was in the midst of severe outbreak and facing a highly uncertain outlook. 
Health systems in the Pacific are generally weak, with significant gaps in access and high burdens of noncommunicable diseases. According to the World Health Organization (WHO), most Pacific island countries annually spend $\$ 500$ or less per capita on health-around half the global average. ${ }^{2}$ Similarly, half of Pacific island countries do not meet the WHO target of having 4.5 health workers for every 1000 persons. The success of most Pacific countries in avoiding large domestic outbreaks of the virus has therefore been fortunate, commendable, and critical, while the health situation in PNG could prove devastating. PNG has around 4000 nurses and 500 doctors servicing a nation of just under 9 million.

Despite most of the Pacific being among the most successful in the world on the health front, the grim reality is that the economic devastation associated with the pandemic is likely to be among the most severe. According to Asian Development Bank (ADB) forecasts, the Pacific region is expected to see an economic contraction of 6.1 percent in 2020 and negligible recovery of 1.3 percent in 2021 (ADB 2020). The most recent IMF forecasts contain a similar outlook, with the Pacific contracting by 8 percent in 2020 and only recovering by 3 percent in 2021. Those economies most heavily reliant on international tourism are being especially hard hit. Fiji is expected to contract by around 20 percent while Palau and Vanuatu are both expected to contract by close to 10 percent.

Beyond tourism, the Pacific is also being negatively impacted by several other factors: first, via reduced global demand for key commodity exports, particularly that emanating from the People's Republic of China (PRC) for energy (PNG) and forestry (Solomon Islands) exports. Second, recessionary conditions in key countries with significant Pacific migrant populations (notably Australia, New Zealand, and the United States) are expected to cause a drop in remittances to the region of around 20 percent (IMF 2020a). Remittances average about 10 percent of GDP in the Pacific islands (excluding PNG), exceeding 40 percent of GDP in Tonga, and at about 15 percent of gross domestic product (GDP) in Samoa and the Marshall Islands. Finally, disruptions to international travel and supply chains are hampering domestic economic activity and stalling the implementation of major public infrastructure projects which are an important short-run driver of growth in many of the smaller Pacific island economies. For example, a major new port in Nauru has been disrupted due to its reliance on imported construction materials and foreign workers.

Like elsewhere in the world, Pacific governments have sought to respond to the economic impact of the pandemic with stimulus packages aimed at keeping their economies and societies afloat through the depths of the crisis. Fiji, PNG, Tonga, and Vanuatu for example have announced packages equal to 8.5 percent, 6.6 percent, 6.1 percent, and 5.6 percent of GDP, respectively, while Samoa's announced package only accounts for 3.1 percent of GDP. ${ }^{3}$ The composition and structure of those packages vary, but in general they comprise a mix of government, banking, pension, and monetary easing measures. Some governments have subsidized the salaries of laid-off workers (e.g., Vanuatu's Employment Stabilization Payment scheme), removed school fees, and are providing tax relief to businesses and workers. Many are also allowing workers to access superannuation savings. Those Pacific economies with their own currencies have also eased monetary policy, although the presence of shallow and underdeveloped credit markets means this can only provide a modest amount of additional support.

Fiscal expansion is the key to responding effectively to the current economic crisis. Despite reasonably large headline numbers attached to announced stimulus packages, the degree of 
actual fiscal expansion is often much more limited (Figure 5.1). Fiscal expansion has been especially constrained in the larger economies of Fiji and PNG. In Fiji, the government has ramped up borrowing dramatically but largely in response to collapsing revenue. In PNG, the government has strived to keep the budget deficit contained. Both PNG and Fiji have been forced to make substantial expenditure savings in other areas of the budget on the order of several percentage points of GDP. Vanuatu has been able to self-finance a larger fiscal expansion by drawing upon cash reserves built up over the past several years. Tonga and Solomon Islands have been able to engage in the greatest degree of fiscal expansion, in large part due to sizable budget support from development partners.

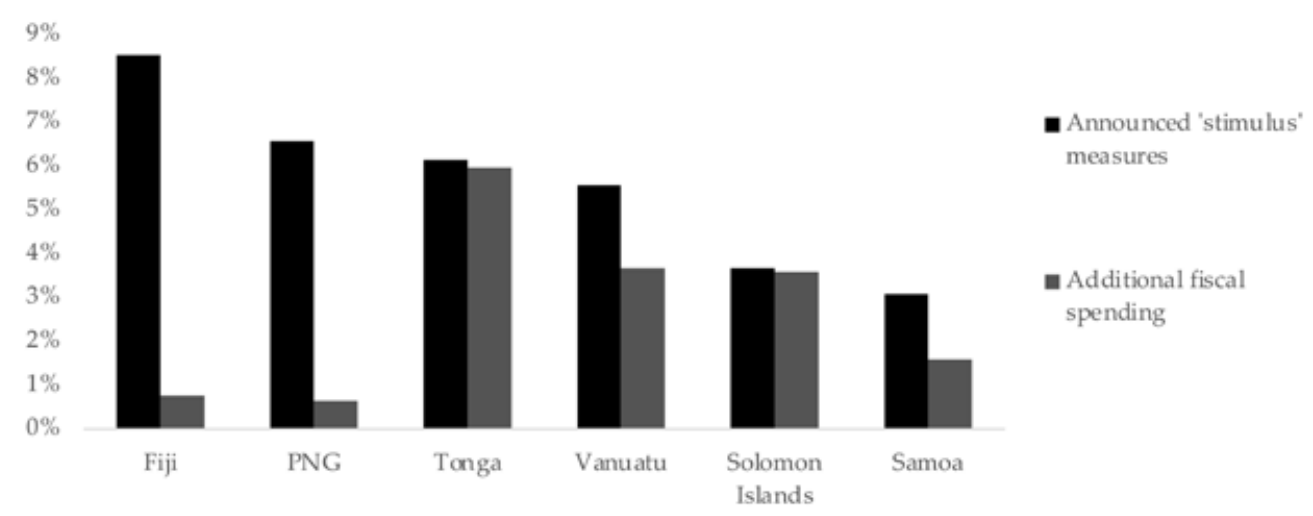

Note: GDP = gross domestic product PNG = Papua New Guinea.

Source: Australian National University, Development Policy Centre. Pacific Covid Economic Database. Accessed at: https://devpolicy.crawford.anu.edu.au/pacific-research-program/pacific-covid-economic-database.

\section{Figure 5.1 Big "stimulus” packages but constrained fiscal expansion (\% of GDP)}

The Pacific's official development partners are providing substantial support in response to the pandemic via a combination of new, redirected and frontloaded financing. To date, we estimate that the Pacific's development partners have announced around $\$ 1.9$ billion (about 5 percent of regional GDP) in prospective COVID-19-related financial assistance, including the G20 debt service standstill, redirected and frontloaded financing from the multilateral development banks (MDBs), expanded IMF rapid financing windows, and reprioritized and increased development assistance from Australia.

This is providing crucial support to the Pacific but with substantial limitations. First, it is difficult to determine how much of the assistance is truly additional, since large amounts of MDB and bilateral funding have simply been redirected from other priorities or brought forward in time (therefore reducing the funds available in future years). Second, only some countries have so far made use of the IMF rapid financing amounts made available, and only in the case of PNG will this be used to help finance the budget deficit, as opposed to simply being added to foreign exchange reserves as balance of payments support.

The fundamental limitation is one of scale, with the international support made available largely only enough to plug the immediate financing gaps caused by drops in government revenue and external income, rather than enabling the kind of large-scale fiscal expansion 
needed to limit the economic damage from the pandemic. Overall, the degree of fiscal expansion in the Pacific has been much lower than that seen in advanced economies, which are typically deploying over 10 percent of GDP to combat the virus in 2020 alone. While larger fiscal responses in advanced economies are perhaps to be expected, this suggests that the economic damage from the crisis in the Pacific is likely to be much deeper and longer-lasting. For instance, the latest IMF forecasts suggest real income per person would not recover to its 2019 level even by 2025 .

\section{A LOOMING PACIFIC DEBT CRISIS?}

Prior to the pandemic, most Pacific economies were already considered to be at an elevated risk of debt distress according to the IMF and the World Bank. Collapsing growth and acute fiscal pressures amid the current crisis therefore suggest that Pacific debt sustainability could now be under considerable threat. Globally there is widespread concern of a looming debt crisis in many parts of the developing world, and international attention is focused on the need to coordinate substantial debt relief. Prior to the pandemic, many developing countries took advantage of easy global liquidity conditions to borrow heavily from private creditors. The PRC also emerged to become the largest official creditor to the developing world. These new sources of debt generally came on less favorable terms than those provided by the MDBs or Paris Club lenders. By the end of 2019, half of all lower-income countries were already considered by the IMF to be at high risk of, or already in, debt distress - up from about a quarter in 2013.

The key question is to what extent the Pacific shares this dire general prognosis.

\subsection{Reasons to Be Concerned: Structural Vulnerability}

Debt sustainability is a perennial concern in the Pacific. The defining developmental characteristic of the Pacific is its extreme geography. The economics of this situation give rise to some of the highest development financing needs in the world while simultaneously greatly reducing the ability of Pacific economies to sustainably carry large amounts of public debt. As a result, there is a structural tension between financing development and safeguarding debt sustainability - a tension now under intense pressure amid the pandemic.

The Pacific's extreme geography is on another order of magnitude compared with any other part of the world (World Bank 2011). These conditions include: an incredibly small size by most key measures (e.g., population, land, and GDP); remoteness from major international economic centers; internal dispersion within countries (both in rural areas and between different islands); dependence on a narrow set of uncertain income sources (notably tourism, remittances, commodities and aid); and high vulnerability to major disasters and the effects of climate change. Nine Pacific countries are for instance among the smallest 25 countries in the world (World Bank 2011). Tonga, Samoa, and Vanuatu—mid-sized Pacific countries - have populations of only 100,000-300,000 (ADB 2018a). PNG is the only exception in terms of size, with a population of almost 9 million. In terms of remoteness, the average Pacific country lies 11,500 kilometers away from the rest of the world weighted by economic size, a 40 percent greater distance than that for the Caribbean islands (Gibson and Nero 2007). In terms of risks to disasters triggered by natural hazards, Vanuatu is considered to be facing the highest risks in the world (Rhur Universitat Bochum 2018). Tonga is considered second. Three other Pacific countries are in the top 10 , including PNG. 
Extreme geography translates into high development financing needs. The Pacific is, by some margin, the most aid-dependent region in the world. The Pacific receives aid equal to around 9 percent of its GDP compared with a figure of 3 percent in sub-Saharan Africa. ${ }^{4}$ Australia, New Zealand, the United States, the PRC, and the MDBs are among the region's major development partners. Despite high levels of aid, the Pacific still faces one of the largest estimated financing gaps of any region. For instance, ADB estimates an infrastructure financing gap of 6.2 percent of GDP every year, the highest such gap of any subregion in Asia and the Pacific (ADB 2017). The World Bank estimates a broader financing gap for infrastructure and human development of around 10 percent of GDP a year (ADB 2018b). It also estimates climate change adaptation needs (e.g., for coastal protection) in the order of 20 percent of GDP for Kiribati and the Marshall Islands and in the range of 5-10 percent of GDP for other Pacific countries (ADB 2018b). In addition, there is the cost of rebuilding following major disasters triggered by natural hazards. For instance, ADB estimates that disasters since 2000 have caused damage equal to 7 percent of regional GDP, with smaller economies worse affected - Vanuatu for instance was hit by a cyclone in 2015 causing estimated damage of over 60 percent of its GDP (ADB 2019).

These same factors work to greatly reduce the ability of most Pacific economies to sustainably carry levels of public debt that in other contexts might be considered less problematic. Public debt sustainability is generally considered as the ability of the government to fully service its debt obligations without the need for unrealistic fiscal adjustment or the compromising of long-term development objectives. The Pacific faces acute structural challenges across many of the core factors in assessing public debt sustainability (IMF 2020b):

- High financing needs to meet economic and social development objectives create pressures toward elevated government spending and budget deficits, especially in the aftermath of major disasters triggered by natural hazards.

- Weak institutional capacity can make undertaking major fiscal adjustments particularly difficult, for instance due to a limited ability to raise additional revenue, achieve spending efficiencies, or effectively manage the distributional impacts on society.

- Relatively weak institutions and the region's economic geography combine to greatly hamper prospects for economic growth, making it difficult to grow out of any debt overhang. Economic growth in the Pacific is more volatile than it is fast (Figure 5.2).

- High exposure to frequent natural hazards and other large negative economic shocks (given generally narrow income sources) creates an ever-present risk of pushing countries from a sustainable debt situation into unsustainable territory. The need to leave room to absorb such shocks means that the "safe" level of public debt at any given time is much lower than otherwise.

Debt sustainability risks as assessed by the IMF have also been rising in the Pacific over the past decade. ${ }^{5}$ Figure 5.3 shows the distribution of IMF debt distress risk ratings across Pacific countries and how this has evolved. Seven of the nine Pacific countries which receive a debt risk rating from the IMF are currently assessed as being at high risk of debt distress, though the IMF still considers debt in these countries to be sustainable. To some extent, the deterioration in these ratings reflects methodological changes by the IMF to better incorporate the impact of frequent natural hazards. Nonetheless, the trend remains that debt sustainability in the Pacific has been moving in a negative direction overall, particularly following a series of 
large negative economic shocks in several countries, including tropical cyclones causing estimated damages of 30-60 percent of output in Samoa, Tonga, and Vanuatu (World Bank 2013; Government of Tonga 2018; Government of Vanuatu 2015).

10

8

6

4

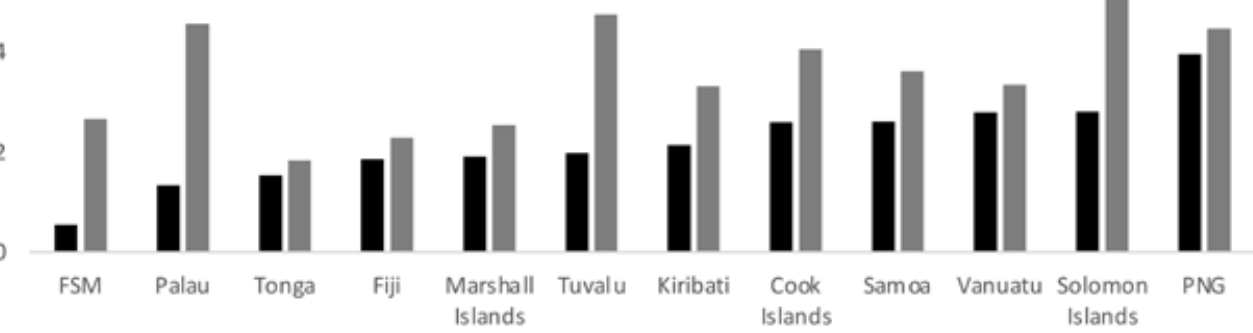

- Average annual growth = Annual standard deviation

Note: $\mathrm{FSM}=$ Federated States of Micronesia; GDP = gross domestic product; $\mathrm{PNG}=$ Papua New Guinea .

Source: Authors' calculations based on IMF.

Figure 5.2 Pacific economic growth is more volatile than fast (\% change in real GDP, 2000-2017)

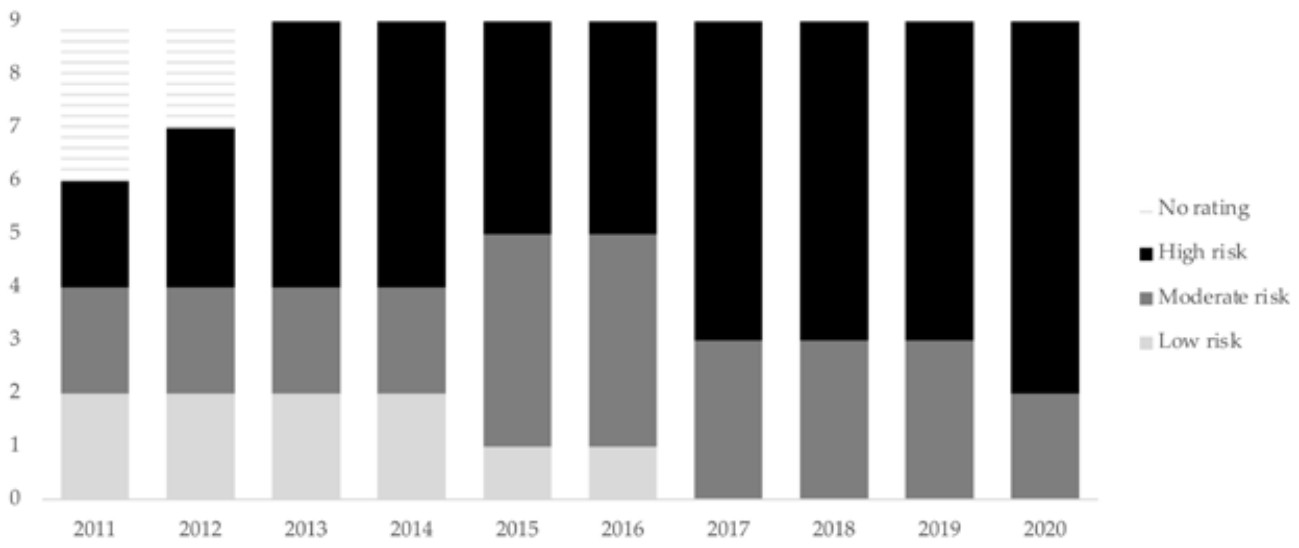

Note: $\mathrm{IMF}=$ International Monetary Fund.

Sources: IMF; World Bank.

Figure 5.3 Worsening debt sustainability risks in the Pacific (most recent IMF risk rating by number of countries) 


\subsection{Reasons to be Less Concerned: The Role of Development Partners}

Unlike many other parts of the developing world, the Pacific did not engage in substantial borrowing from international private creditors prior to the crisis. It therefore largely does not face the same rollover problems or complications in negotiating debt relief. The PRC has become a major source of external loans in the region. Again, however, the Pacific does not appear to have followed the pattern seen elsewhere, with bilateral loans from the PRC mostly provided on semi-concessional terms. Public debt servicing costs in the Pacific have therefore remained much lower than elsewhere, providing much more favorable debt dynamics. Finally, some caution is needed in interpreting the IMF debt sustainability analyses for many of the more aid-dependent Pacific economies, which for technical reasons explained below tend substantially to overstate the risk of debt distress in these economies.

A major favorable factor for Pacific debt sustainability is the region's heavy reliance on official development partners when it comes to public sector borrowing. For most Pacific developing economies, debt owed to development partners constitutes the vast majority of their external debt obligations (Figure 5.4). Only PNG and Fiji have some limited access to borrow from international private creditors, outside of crisis times. PNG and Fiji are also the only countries that borrow domestically to a large extent, with this constituting around three-quarters of total public debt in Fiji and around 40 percent in PNG. However, both still borrow predominantly from development partners when it comes to contracting external debt.

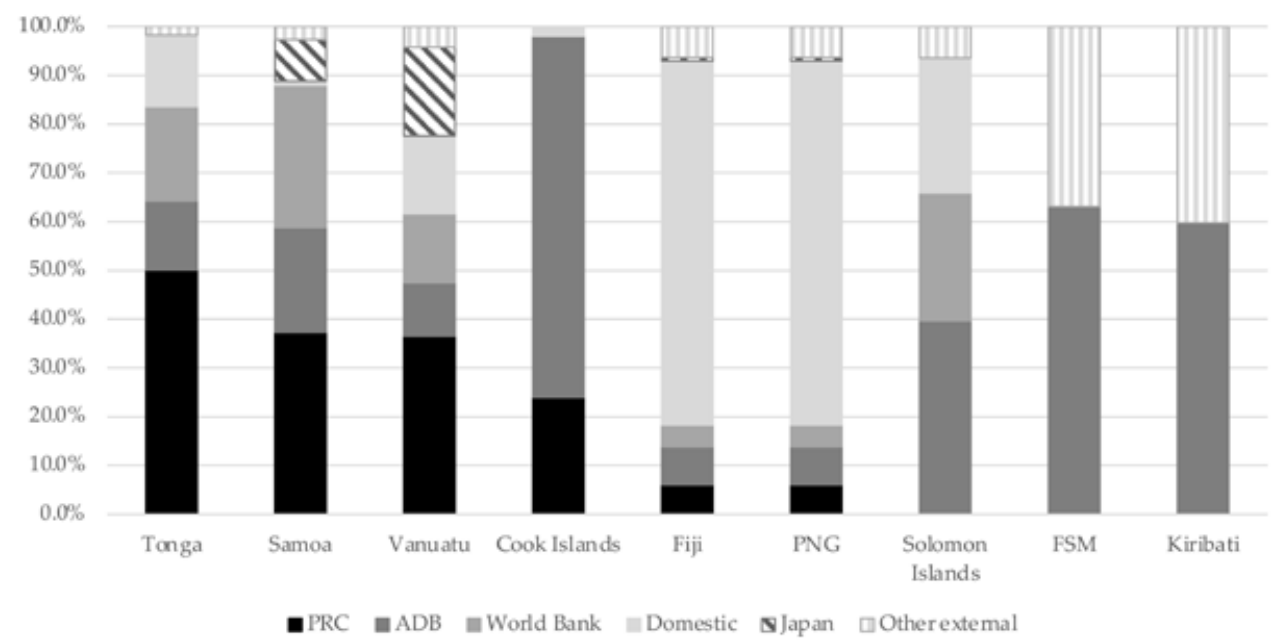

Note: $\mathrm{FSM}=$ Federated States of Micronesia; PRC = People's Republic of China; PNG = Papua New Guinea. Sources: Authors' calculations; government budget documents; and IMF.

Figure 5.4 Pacific development partners constitute most of debt obligations (share of debt stock by creditor type) 


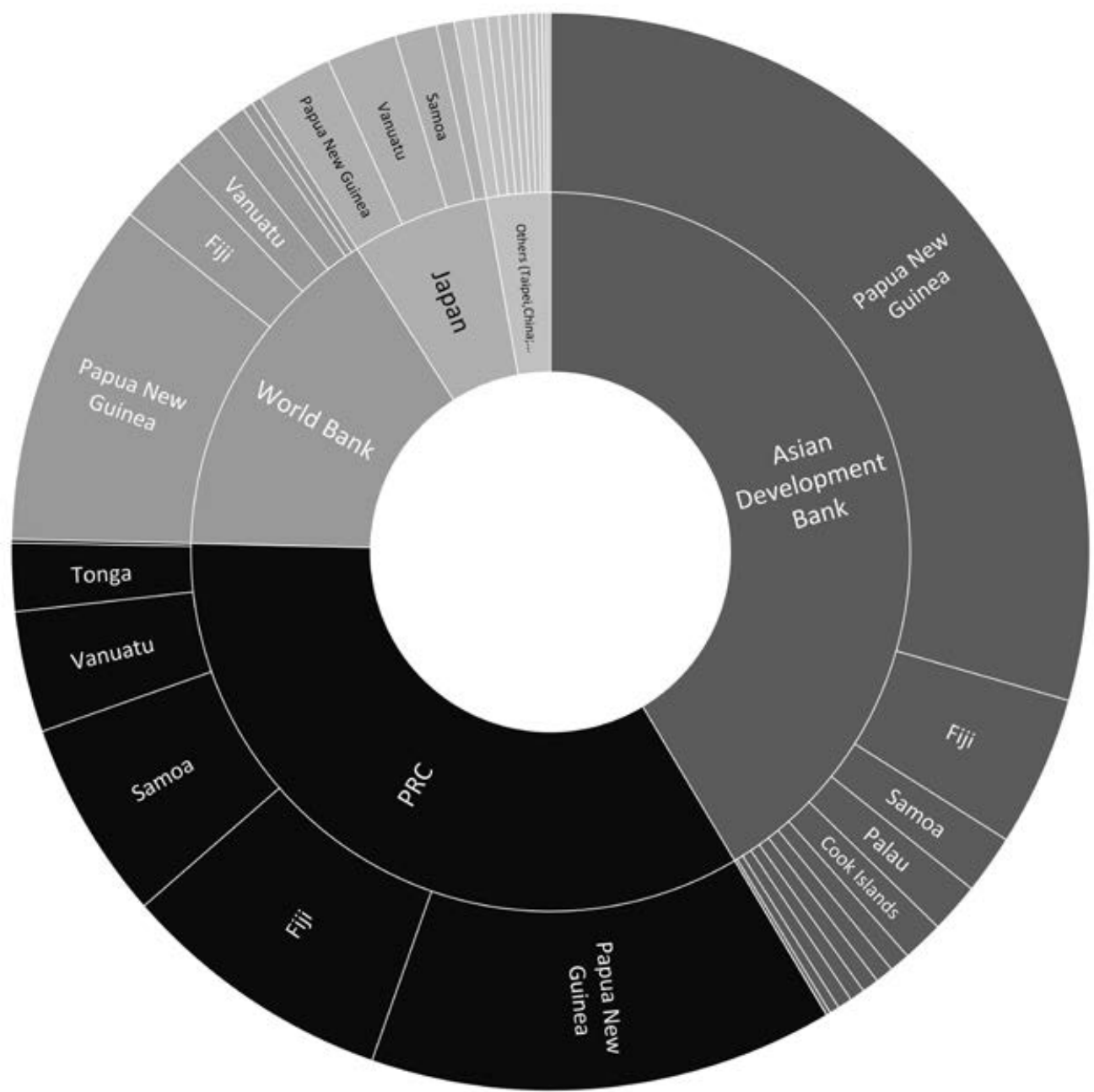

Note: PRC $=$ People's Republic of China.

Source: Authors based on Lowy Institute Pacific Aid Map.

Figure 5.5 Cumulative loan flows by creditor-borrower disbursements, 2010-2018

ADB is the largest single external lender in the Pacific. Together with the World Bank, which operates at a considerably smaller level, the two multilateral development banks account for almost 60 percent of all new loans to the region in recent years (Figure 5.5). The PRC has become a major source of new loans over the past decade or so, being the second largest single creditor in the Pacific and the largest bilateral lender. Much further down the scale, Japan and Taipei,China are also important lenders while Australia has recently begun providing bilateral 
loans to the Pacific, though prior to COVID-19 it had only extended a single "bridging" loan to PNG.

The large role of official creditors in the Pacific means that government borrowing terms tend to be quite favorable. Debt transparency is limited. However, most public debt in the Pacific appears to be contracted on a concessional or semi-concessional basis. Here we use the criteria for concessional loans employed by the IMF and multilateral development banks (IMF 2015). Alternative, less-stringent criteria are used by the OECD-DAC. Here, we will refer to loans that meet the OECD-DAC criteria, but not the more stringent IMF criteria, such as "semi-concessional", recognizing that such loans remain far less expensive than those available from the market. ${ }^{6}$

Most Pacific countries are eligible for grants and concessional loans from ADB and the World Bank. Fiji, PNG, and the Cook Islands have access to ordinary loans from the MDBs (although it should be noted that these still meet our definition as "semi-concessional"). The PRC's lending terms are less transparent than other official creditors. Independent research efforts suggest that, at the global level, most Chinese official lending is provided on a non-concessional or commercial basis. ${ }^{7}$ However, in the Pacific there appears to be a different pattern, with the vast majority of Chinese official lending taking the form of "concessional loans" from the EXIM Bank of China (Rajah et al. 2019). These have tended to carry an interest rate of 2 percent, 5-7 years grace period, and 15-20 years' maturity-qualifying as semi-concessional loans by our standard.

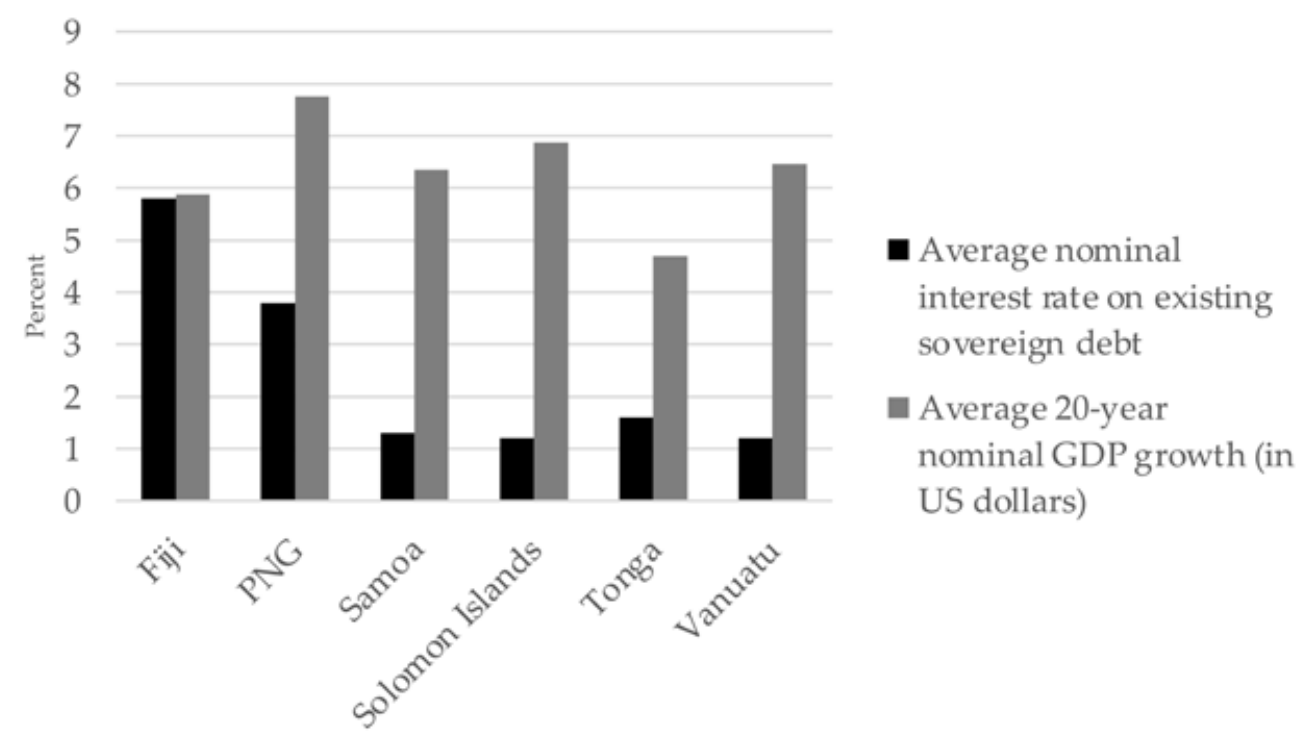

Note: GDP = gross domestic product; $\mathrm{PNG}=$ Papua New Guinea; US = United States.

Sources: Authors' calculations; IMF World Economic Outlook database; and IMF country debt sustainability analyses (various years).

Figure 5.6 Sovereign borrowing costs in the Pacific are low and contribute to favorable debt dynamics 
The upshot is that sovereign borrowing costs in the Pacific are low enough to generate quite favorable debt dynamics, even when compared with the region's generally weak historical growth experience (Figure 5.6). The major role of official development partners in the region's debt profile means that the average interest rate on existing public debt tends to be less than 2 percent for most Pacific countries, though it is considerably higher for PNG and Fiji, which also borrow from private external creditors and domestic sources. With the exception of Fiji, average borrowing costs are well below historical rates of nominal output growth measured in US dollars-implying interest-growth differentials have generally been quite favorable, or at least neutral in the case of Fiji, even after accounting for movements in the exchange rate. The overwhelmingly dominant role of concessional financing also means that, prior to the COVID-19 pandemic, the Pacific had not followed the global trend toward increasingly worrisome external debt servicing requirements (Figure 5.7).

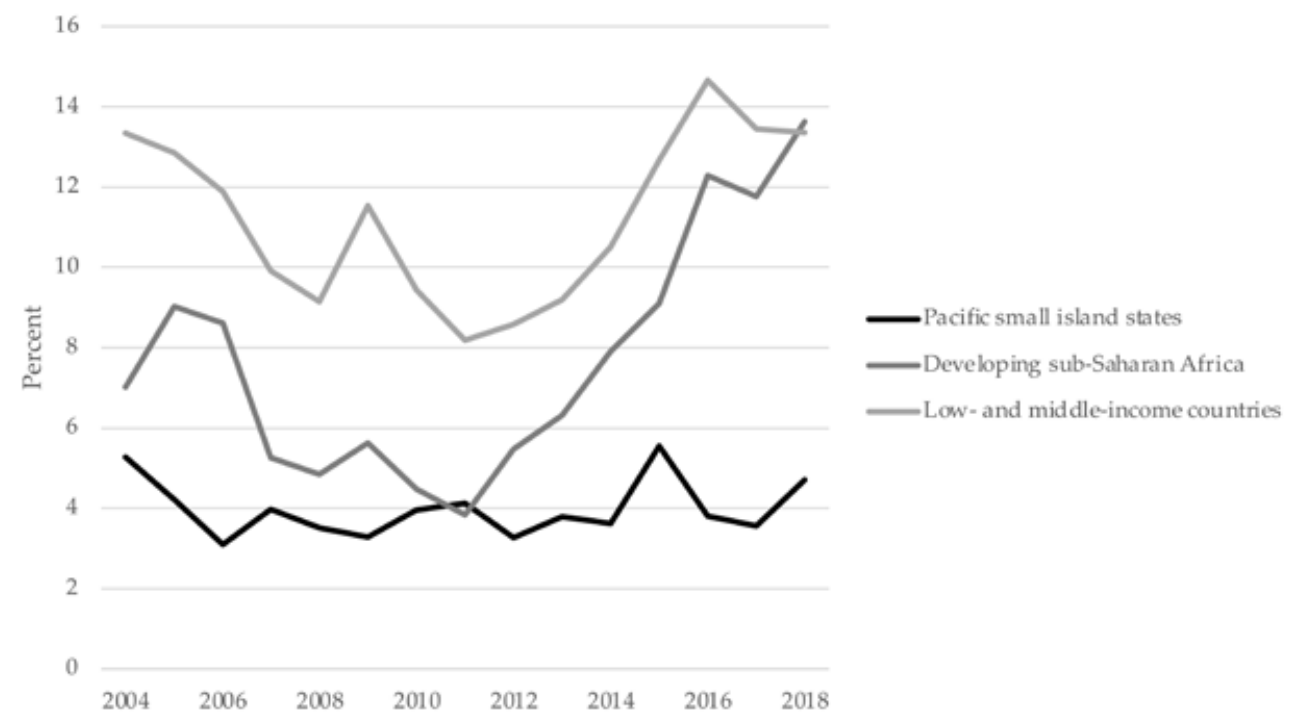

Sources: Authors' calculations; World Bank. World Development Indicators.

Figure 5.7 External debt service requirements in the Pacific are much lower than elsewhere in the developing world heading into COVID-19 (ratio of external debt service to goods and services exports + primary income)

Finally, it is worth scrutinizing the debt sustainability analysis produced by the IMF. This is taken up in more detail in the next section for our four key case study countries. However, there is an important general point of caution when it comes to interpreting the IMF debt risk ratings for many of the smaller and more aid-dependent Pacific economies, as these assessments tend to overstate the risk of debt distress by design.

The key issue is that these heavily aid-dependent economies have access to the most concessional financing windows from the MDBs, which in turn follow specific rules that adjust to the prevailing risk of debt distress, as encapsulated by the IMF ratings. Countries that are rated as 
low risk receive their country allocations in concessional loans while those at high risk receive outright grants. Countries at moderate risk receive 50:50 in grants and concessional loans. This potentially creates a loop of logic, whereby the IMF could rate a country as being at low risk of debt distress only for that country to receive large MDB loans that pushed them to a high risk. To avoid this perverse result, the standard IMF approach is to assume that all financing from the MDBs is provided entirely on credit, rather than grant, terms. ${ }^{8}$ The problem is that doing so artificially inflates the projected size of future primary budget deficits, since it ignores MDB grants as a likely source of future government income and treats this as a debt-creating flow instead. This is less of a problem for near-term forecasts in the IMF analyses, as the IMF includes MDB grants that have already been committed. But it can have an important impact on medium-to-long-term debt projections.

The implications are potentially quite significant given the scale of MDB financing in the Pacific. For the smaller, more aid-dependent Pacific economies, MDB financing typically accounts for around 4 percent of GDP and the banks have been scaling up their Pacific operations in recent years (Figure 5.8). As noted earlier, seven of nine Pacific countries eligible for concessional MDB financing are already rated as being at high risk of debt distress and therefore are receiving entirely grant financing from the MDBs while the other two countries are at moderate risk and receiving 50:50 loans and grants. It is difficult to ascertain precisely how large an effect this has on the IMF's analysis. However, our case studies of Samoa and Tonga in the next section suggest that the impact is significant and substantially worsens the assessed debt outlook for these countries. The upshot is that, while serving as a useful decision-making tool for the MDBs, the IMF debt sustainability risk ratings for many countries are no longer based on what is most likely to happen, reducing their usefulness as an early warning indicator and overstating the true risk of debt distress.

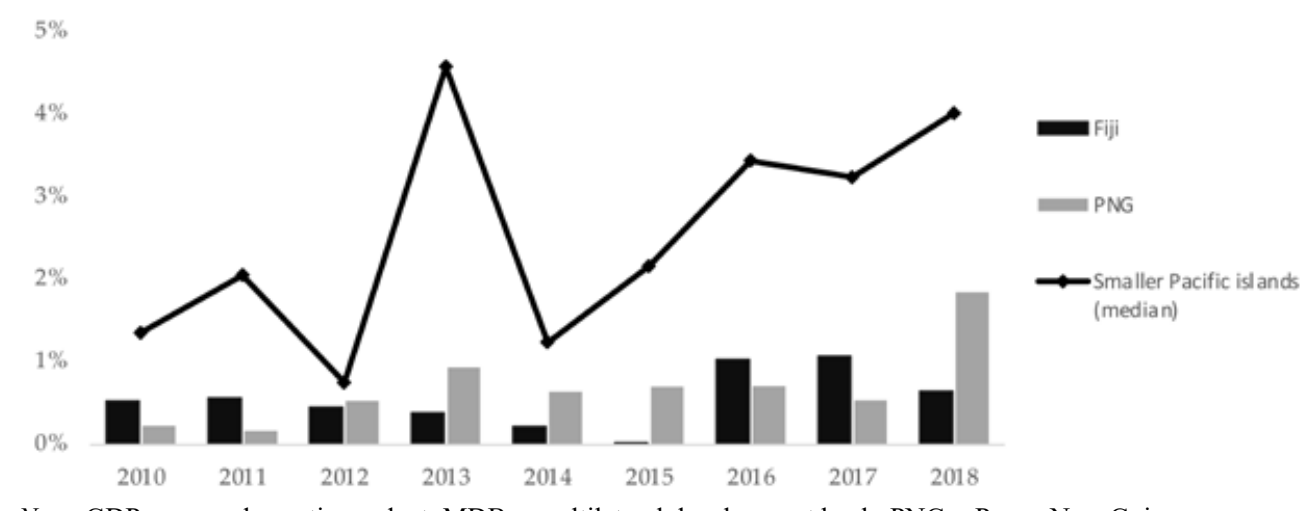

Note $:$ GDP = gross domestic product; $\mathrm{MDB}=$ multilateral development bank; $\mathrm{PNG}=$ Papua New Guinea.

Sources: Authors' calculations; Lowy Institute Pacific Aid Map; and World Bank. World Development Indicators.

Figure 5.8 Concessional MDB funding is large for the smaller Pacific economies (total annual disbursements as an average share of GDP) 


\section{A MORE DETAILED LOOK AT FOUR CASE STUDIES}

We now take a closer look at debt sustainability in Fiji, PNG, Samoa, and Tonga-as the countries arguably facing the most uncertain debt prospects due to COVID-19. In each case, we consider the findings of the most recent IMF debt analyses and construct our own scenario projections for these countries to further scrutinize the outlook for longer-term public debt sustainability or "solvency".

Our scenario projections follow the same approach as the IMF in terms of both the overall framework and the specific assumptions for most key variables - only varying these to the extent necessary for the purposes of our analysis. We focus on the debt-to-GDP ratio as the key summary measure of the overall burden of servicing public debt. Following the standard IMF approach for low-income countries (which is used for most Pacific countries), we focus on the present value (PV) of debt- that is, adjusting for the degree of concessionality inherent in any loans - and compare the resultant PV debt-to-GDP ratio with the warning thresholds used by the IMF. These warning thresholds are in turn determined by whether the IMF assesses the country to have a strong, medium, or weak debt-carrying capacity. In addition to a baseline scenario, we define several alternative scenarios, including a prolonged recession due to the pandemic, the full realization of any contingent liabilities, or severe natural hazards in the near future. Longer-term risks from major disasters triggered by natural hazards in Samoa and Tonga are incorporated into the long-term assumptions for growth and the primary fiscal balance, following the same approach used by the IMF.

A perpetually rising or "explosive" debt ratio is a telltale sign that the trajectory of public debt is unsustainable. Conversely, a declining debt ratio generally indicates the opposite. Following the standard IMF guidelines, if the debt ratio rises above the warning threshold in the baseline scenario by a substantial margin or on a sustained basis, this can be taken as a major warning sign. Marginal or temporary breaches are less concerning. Breaches only in the stress test scenarios indicate a moderate risk.

Perhaps the most critical variable in all of this is the future fiscal effort of government, as captured by the primary budget balance (i.e., excluding interest payments). The trajectory of public debt depends critically on the scale of expected future government borrowing and the ability or willingness of governments (and societies) to rein this in where needed. Rather than relying on promises of future fiscal prudence or assumptions about continued fiscal profligacy, we consider a more objective approach to be whether the required primary surpluses needed to stabilize or bring down the debt-to-GDP ratio over the medium-to-long term is within the range of a country's historical performance. If this is the case, then it seems reasonable to conclude that the level of public debt can be sustainable with a realistic amount of fiscal effort. To operationalize this in what follows, we take as our baseline for each country the latest IMF projections for 2020-2025 and the average primary balance over the last 20 years for the longer-term outlook.

The rest of this section focuses on each of the country case studies. The appendix summarizes the basis of our key assumptions and projections for each country in the baseline scenario. 


\subsection{Debt Sustainability in Fiji}

Fiji appears the most vulnerable in the Pacific. Prior to the pandemic, the government had intended to pursue a medium-term strategy of fiscal consolidation aimed at bringing down debt-to-GDP to more manageable levels. Now, with both its tourism-dependent economy and revenue collapsing, the government is expecting a budget deficit of around 20 percent of GDP in FY2021 (fiscal year ending on 31 July 2021).

The IMF is yet to prepare an updated debt sustainability analysis for Fiji. In an assessment letter dated June 2020, the IMF states that Fiji's public debt was sustainable but vulnerable (Republic of Fiji 2020). Large bullet payments to international bondholders are being refinanced with new loans from the MDBs, which should reduce the contribution of external debt to Fiji's balance of payments pressures. Fiji's other external debt service payments are less than 1 percent of GDP in FY2021. ${ }^{9}$ However, this early IMF assessment appears to have been overtaken by the ongoing crisis, with the Government of Fiji since announcing a much larger budget deficit in 2021 than assumed by the IMF. ${ }^{10}$ Fiji's public debt prior to the pandemic was already among the highest in the Pacific at around 50 percent of GDP. It is now expected to reach 84 percent in FY2021 (ADB 2020).

How much is too much? Although Fiji is considered a market access country by the IMF for the purposes of assessing debt sustainability, it is informative to employ the techniques used by the IMF for assessing debt sustainability in low-income countries. This makes some sense given that semi-concessional loans account for three-quarters of Fiji's external debt. The first step is to correct for the concessionality of Fiji's debt profile by focusing on the present value of public debt, rather than its face value, relative to GDP. This can then be compared against the standard IMF warning thresholds used for low-income countries. Given that this framework is intended for countries with generally weaker institutions and more fragile economies, we use the benchmark for those with a strong debt-carrying capacity and treat this as a conservative warning indicator for Fiji.

The debt outlook in Fiji depends crucially on when and to what extent Fiji's tourism industry can recover and how this interacts with the primary budget balance. For our baseline we draw upon the latest forecasts from the IMF. The IMF expects Fiji's economy to contract by 21 percent in FY2021 before rebounding 11.5 percent in FY2022 and settling into a more gradual recovery thereafter, only returning to its FY2019 level of real output in FY2023. This would be consistent with a slow and partial recovery in tourism beginning in FY2022 and with the industry remaining well below its pre-COVID trajectory. For the primary balance, the IMF projects that Fiji would bring down its primary deficit rapidly, from 13 percent of GDP in FY2021 to just 4 percent of GDP the following year and moving into modest surpluses over the following years.

Using the latest IMF projections to inform our baseline scenario suggests that Fiji's debt outlook is precarious but still within the range of sustainable (Figure 5.9). Fiji's debt ratio spikes higher in FY2021 to reach the warning threshold but eases back down below this thereafter as economic recovery gradually takes hold and fiscal consolidation is pursued. However, Fiji's debt situation is also very precarious and highly sensitive to how the crisis plays out. Figure 5.9 shows several alternative scenarios that highlight the key risks:

- First, a more drawn-out economic crisis - particularly via a slower recovery in international tourism - could have severe implications. In our "delayed tourism recovery" 
scenario, we assume the recovery is pushed back by a full year, with growth at zero and the budget deficit remaining at 20 percent of GDP in FY2022. The debt ratio jumps to 92 percent.

- Second, a delayed tourism recovery would also make it more likely that the government could be forced to realize sizable contingent liabilities, estimated to total over 20 percent of GDP. Most notably, in response to the crisis the government has extended large guarantees to state-owned airline, Fiji Airways. If contingent liabilities were fully realized, this alone would push debt to almost 100 percent of GDP.

- Third, it is worth noting that the IMF is currently projecting quite significant fiscal consolidation to occur over the coming years, despite the fact that Fiji's economy would still be operating well below any reasonable notion of potential during this period. The risk is that this proves overly optimistic. We therefore also consider a "slower fiscal consolidation" scenario, with the primary budget balance remaining in deficit for longer and only slowly converging to a small surplus of 0.3 percent of GDP by FY2027 (in line with Fiji's 20 -year historical average). In that case, Fiji's debt ratio would rise further above the warning threshold, remaining there for the foreseeable future.

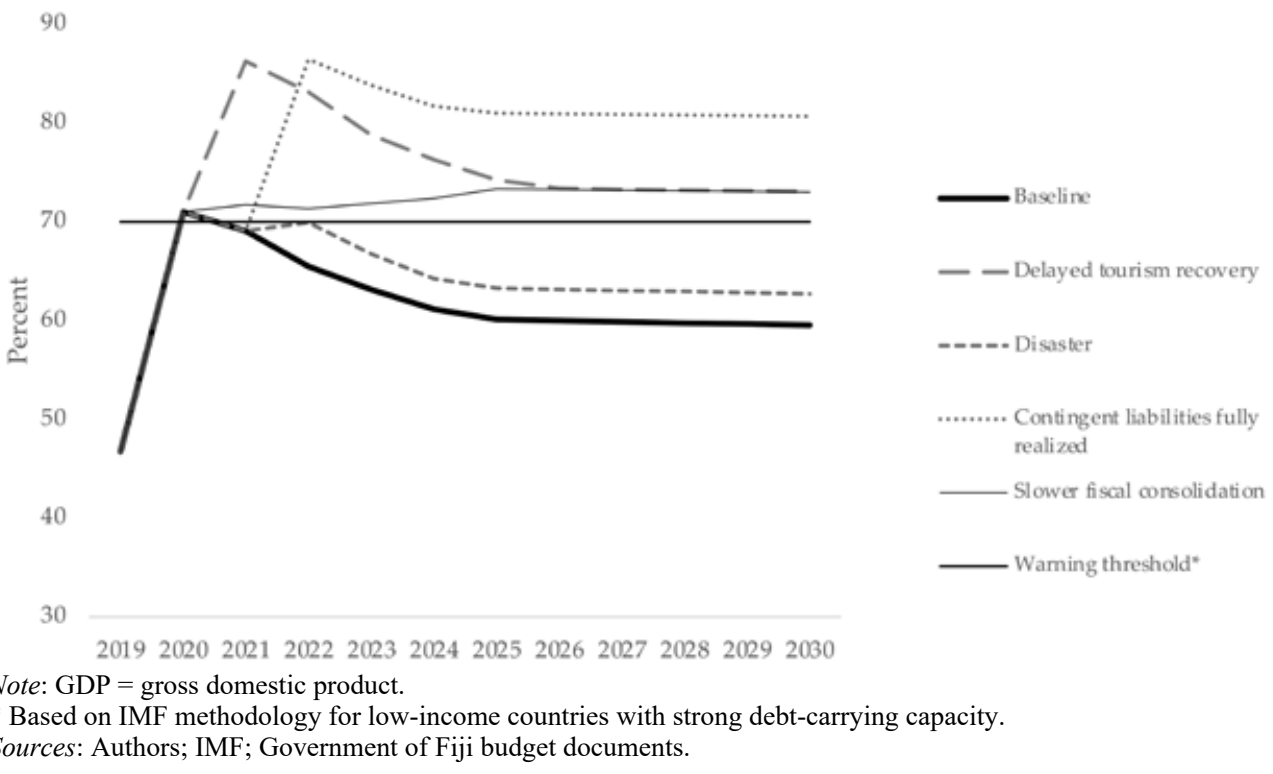

Figure 5.9 Fiji's public debt sustainability is extremely precarious and requires strong fiscal effort to bring to a more sustainable position (ratio of present value of public debt-to-GDP under different scenarios)

One consolation is that Fiji's problems are primarily about domestic rather than external debt. Fiji's external public debt burden is relatively low and will likely hover at 10-15 percent of GDP in present value terms over the coming decade - far below the 55 percent warning threshold for low-income countries. Having the majority of public debt denominated in Fiji dollars 
and held by domestic residents avoids the risks normally associated with external borrowing. It also gives the government somewhat more room to maneuver without necessarily triggering an acute debt crisis - for example, through financial repression or de jure default via higher inflation.

\subsection{Debt Sustainability in PNG}

The COVID-19 crisis hit PNG at an inopportune time. After years of sluggish growth, persistent budget deficits and rising debt, the government had only just embarked on a new reform drive, in cooperation with the IMF and other development partners, aimed at reinvigorating the economy, strengthening governance, and bringing down public debt over the medium term to within the legally mandated range of 30-35 percent of GDP.

The IMF updated its assessment of PNG debt sustainability in June 2020. According to the IMF, public debt in PNG remains sustainable, although the IMF increased the risk of debt distress to "high" compared with a "moderate" rating prior to the pandemic. However, it is worth noting that the specific drivers behind this downgrade essentially relate to short-term liquidity problems, rather than major changes in the IMF's assessment of longer-term solvency. In terms of external debt, the main concern is elevated external debt service payments in 2020, which have already been refinanced with concessional loans. ${ }^{11}$ In terms of domestic debt, the main issue relates to rollover risks associated with PNG's reliance on short-maturity debt securities. Otherwise, the IMF's baseline projections for key debt sustainability indicators are well below the warning thresholds. ${ }^{12}$ In sum, the IMF analysis suggests that the risks to PNG's debt outlook are almost entirely about short-term liquidity whereas public sector solvency does not appear to be under immediate threat.

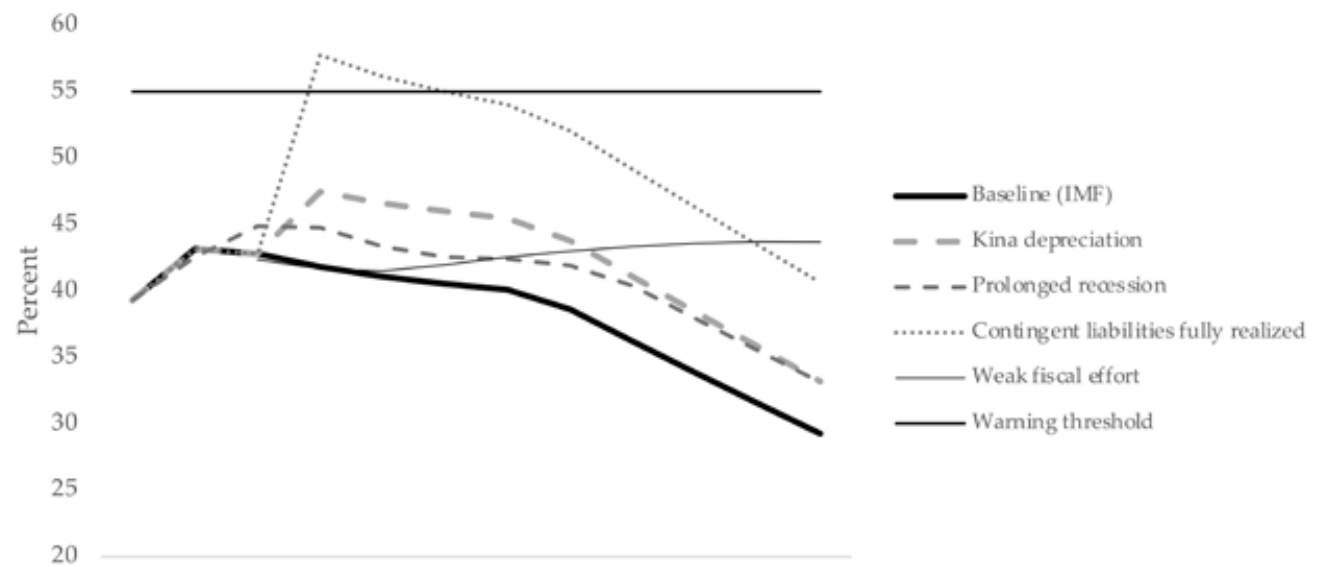

201920202021202220232024202520262027202820292030

Note $:$ GDP = gross domestic product; IMF = International Monetary Fund; PNG = Papua New Guinea. Sources: Authors; IMF; Government of PNG budget documents.

Figure 5.10 PNG public sector solvency has some room to maneuver (ratio of present value of public debt to GDP under different scenarios) 


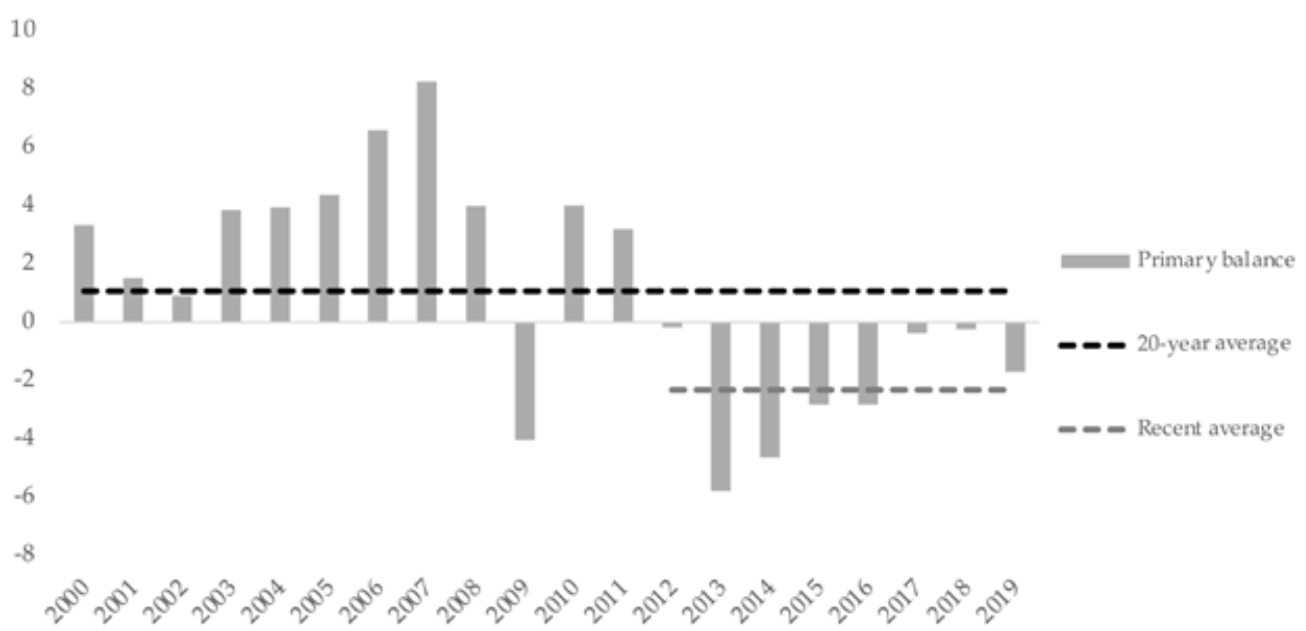

Note: GDP = gross domestic product; $\mathrm{PNG}=$ Papua New Guinea.

Source: Authors based on IMF World Economic Outlook October 2020 database.

\section{Figure 5.11 PNG's variable fiscal performance (primary balance, \% of GDP)}

To test this judgment, we replicate and expand on the IMF analysis to consider a few alternative scenarios of particular interest. This is presented in Figure 5.10. Our analysis confirms this relatively benign picture for PNG public sector solvency:

- The biggest risk is if sizable contingent liabilities - mostly related to disputed sovereign guarantees of state-owned enterprises and unfunded pension liabilities - were fully realized. Although this results in a sharp jump in the debt-to-GDP ratio above the warning threshold, the breach is short-lived and therefore not a major signal of potentially unsustainable debt (our scenario is the same here as that used by the IMF).

- Another point of concern is that the PNG exchange rate is widely seen as overvalued and could depreciate, inflating the size of external public debt. The IMF estimates that the kina is overvalued by 11-18 percent. We take the high end of this range for our "kina depreciation" scenario. However, the impact is relatively contained. Although external debt is about 60 percent of overall public debt, most of this is on semi-concessional terms and therefore represents a smaller debt burden when measured in present value terms.

- Next, we consider the impact of a prolonged recession-which could result for instance if the early 2021 surge in virus cases is not brought quickly under control or if the global downturn affecting PNG's commodity exports proves more drawn out than expected. The "prolonged recession" scenario assumes that economic recovery is pushed back by a full year, with growth at zero in 2021 and the primary deficit remaining at 3.4 percent of GDP. As the figure shows, this result would not substantially alter PNG's long-term debt trajectory.

- Finally, a major reason behind PNG's relatively benign long-term debt outlook (including in the above scenarios) is the combination of relatively low real borrowing costs and the IMF assumption that PNG will stick to a prudent fiscal policy going forward. How 
sensitive is the debt outlook to this assumption? In our "weak fiscal effort" scenario, we assume that PNG immediately returns to the primary deficits seen during most of the past decade of around 2.3 percent of GDP (Figure 5.11). This shifts the trajectory of public debt substantially. Even then, however, the debt-to-GDP ratio remains well below the warning threshold through the rest of this decade and would not breach the threshold by 2040 .

What can we conclude? PNG's debt situation has certainly been worsened by the pandemic. But the most recent IMF assessment that the trajectory of public debt is sustainable seems well justified, even when we consider the scope to absorb more negative scenarios such as a prolonged recession or weaker fiscal effort. Public sector solvency in PNG does not appear under serious immediate threat.

\subsection{Debt Sustainability in Samoa and Tonga}

Samoa and Tonga both entered the current crisis with their economies and public finances in significantly weakened condition. Samoa experienced a severe measles outbreak in late 2019 which substantially damaged its tourism industry even before the pandemic hit. Tonga meanwhile had not yet fully recovered from Tropical Cyclone Gita in 2018, which had dealt estimated damage worth around 40 percent of GDP, as well as being hit by three more cyclones since. Public debt in Samoa and Tonga was already considered to be at high risk of debt distress by the IMF, reflecting elevated debt levels in both countries and their high exposure to severe natural hazards. Both countries are also among those that have taken on large semi-concessional bilateral loans from the PRC in recent years, despite being at high risk of debt distress. Tonga in particular faces large impending debt repayments related to these loans, starting in FY2024.

The IMF has completed a full update of its analysis for Samoa since the pandemic, maintaining its high-risk rating but also its overall conclusion that Samoa's debt outlook remains sustainable. The IMF is yet to release an updated assessment for Tonga. But in an April 2020 assessment letter, the IMF stated that Tonga continued to be at high risk of debt distress, with the PV debt-to-GDP ratio expected to eventually breach the warning threshold and fiscal and foreign exchange reserve buffers run down to unsafe levels.

As noted in the previous section, however, care must be taken in interpreting the IMF ratings for Samoa and Tonga. Both are eligible for concessional funding from the MDBs and, given that both are rated as being at high risk of debt distress, this will very likely be provided on 100 percent grant terms for the foreseeable future. Yet the standard IMF approach is to assume that this will be provided on full credit terms. It is difficult to ascertain precisely how large an impact this has on the IMF's analysis - with near-term projections affected by an unclear amount of already committed MDB grant funding while longer-term projections depend on unknown assumptions about the scale of future MDB financing. But the impact is likely to be very substantial in terms of the medium-to-long-run debt trajectory. First, as Figure 5.12 shows, the MDBs are a significant source of financing for both Samoa and Tonga, generally amounting to between 2 percent and 5 percent of GDP in any given year. Second, there is a large gap between both countries' historical fiscal performance and IMF projections of the future primary balance - probably related to the IMF assumption that future MDB financing will take the form of loans rather than grants. 


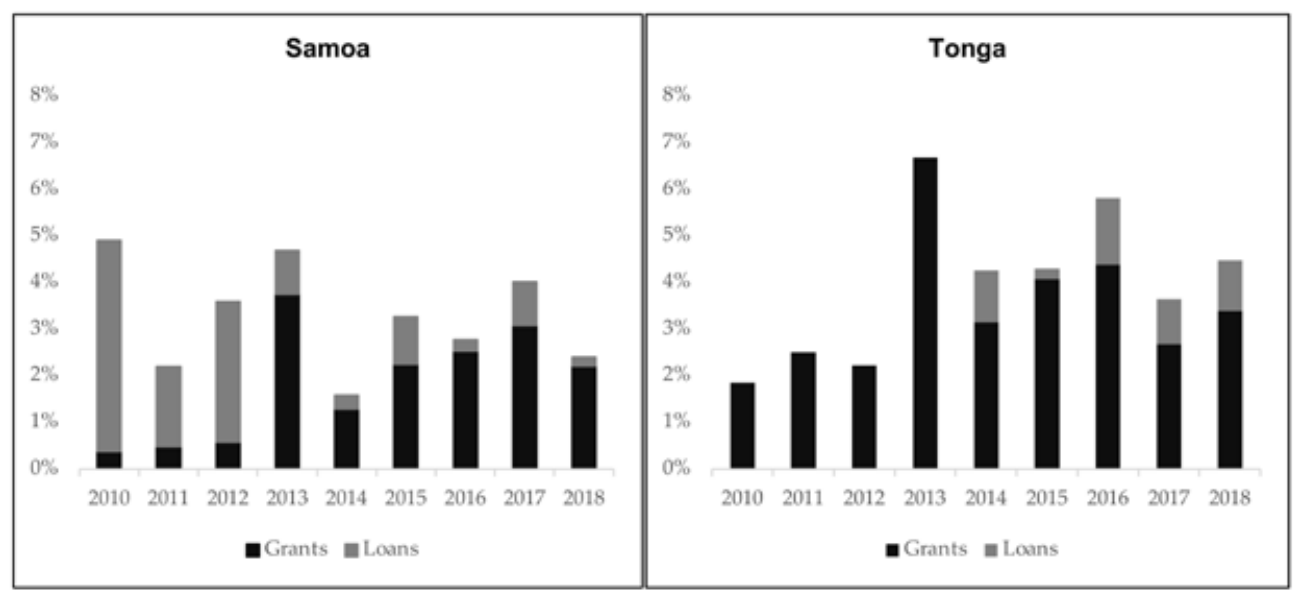

Source: Authors' calculations based on Lowy Institute Pacific Aid Map and World Bank World Development Indicators.

\section{Figure 5.12 Concessional MDB financing is significant in Samoa and Tonga (MDB} disbursements as \% of recipient GDP)

For Samoa, the IMF analysis assumes the primary deficit will average 5.2 percent of GDP over the long term, including an allowance of 1.5 percentage points of GDP for the average annual cost of disasters triggered by natural hazards..$^{13}$ By comparison, over the past two decades Samoa recorded a budget deficit averaging 2.0 percent of GDP. This already includes the historical impact of past disasters triggered by natural hazards. But even if an extra 1.5 percentage points of GDP in further disaster costs were added, this would still leave the average deficit at 3.5 percent of GDP. Focusing only on the last decade, the respective numbers would be a deficit of 3.1 percent of GDP or 4.6 percent with the added disaster costs. The gap between Samoa's historical budget performance and the IMF long-term assumption is therefore $0.6-1.7$ percentage points each year, implying a large difference in assumed borrowing over the 15-year forecast horizon it applies to. Either the IMF is far more pessimistic about Samoa's fiscal performance than this historical approach would suggest, or the difference must largely reflect the (unrealistic) assumption of future MDB loan financing rather than grants.

Using its historical fiscal record as a guide suggests that Samoa's public sector solvency is less concerning than that suggested by the IMF analysis. Figure 5.13 shows our projections for the PV public external debt-to-GDP ratio. We focus on external debt as most public sector borrowing is from external sources, and Samoa is much closer to breaching the external debt warning threshold. In our baseline, we assume that Samoa's primary balance converges to an average deficit of 3.5 percent of GDP - that is, the 20-year historical average less an additional 1.5 percentage points of GDP in extra disaster costs. Our weak fiscal effort scenario uses the 10-year average performance instead, with the long-term deficit of 4.6 percent of GDP.

Samoa's debt ratio remains well below the warning level until at least 2030, even with an extended recession or weaker fiscal effort (Figure 5.13). Samoa would also remain below the threshold in the case of a severe disaster triggered by natural hazards. We also show the debt 
ratio if the IMF primary balance assumption is applied, which results in a sharply rising debt ratio by later in the decade which would eventually reach the warning threshold in the early 2030s (which is the basis on which the IMF judges Samoa to be at high risk of debt distress). By contrast, our baseline debt ratio would still be slightly below the warning level even in 2040. Using the weak fiscal effort scenario, the debt ratio would reach the threshold in 2035.

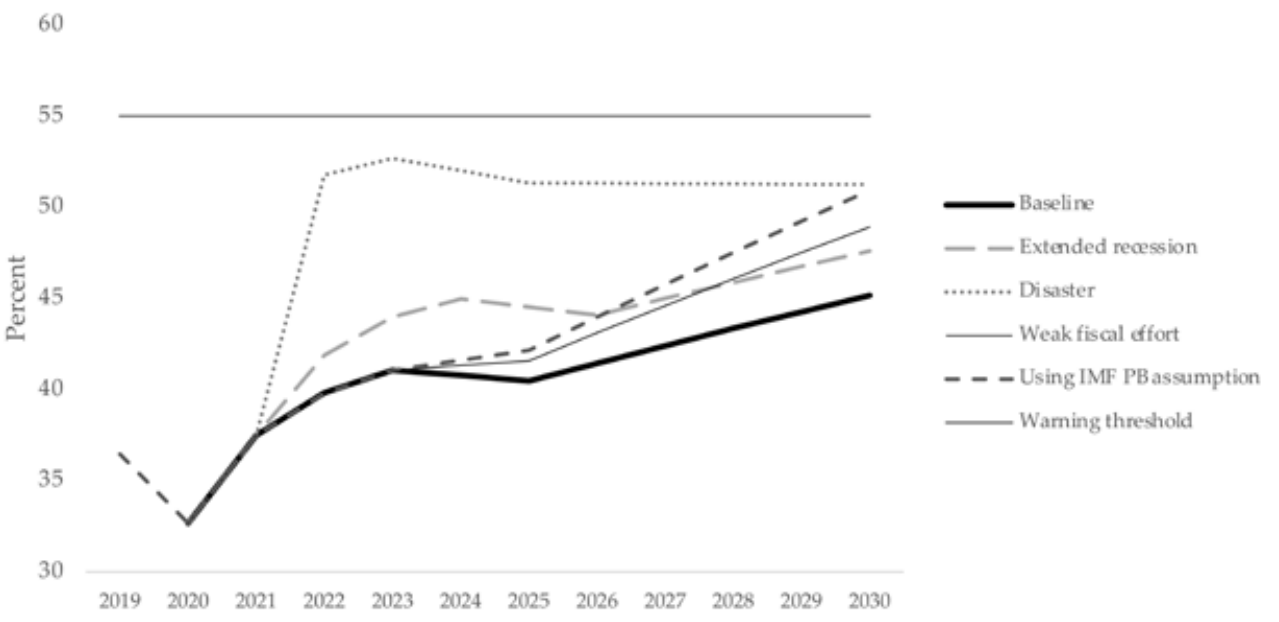

Note: GDP = gross domestic product; IMF PB = International Monetary Fund primary balance.

Sources: Authors; IMF; Government of Samoa budget documents.

Figure 5.13 Samoa's public sector solvency is less worrying than it seems (ratio of external public debt-to-GDP under different scenarios)

Repeating a similar exercise to the above, the picture in Tonga is also starkly better than that suggested by the IMF analysis and by a more substantial degree than in the case of Samoa. Tonga faces significant debt risks in the short term, particularly from an extended recession or if a severe disaster triggered by natural hazards were to hit in the near term (Figure 5.14). However, these would only result in short-lived breaches of the warning threshold. Overall, debt sustainability looks much less troubling than if we were to use the IMF's assumption for the long-run primary balance. ${ }^{14}$ The difference between the IMF assumption for the average long-run primary balance and the 10-20-year historical performance is much larger in the case of Tonga, at 2.1 to 3.4 percentage points of GDP. Over the past two decades Tonga recorded a primary surplus averaging 2.6 percent of GDP, compared with the long-run IMF assumption of a deficit of 0.8 percent of GDP (before adding in average disaster costs). Potentially this reflects that Tonga receives more MDB financing relative to the size of its economy compared with Samoa. In any case, it seems that the scale of regular MDB grant financing would easily cover this difference. Even with relatively weak fiscal effort, Tonga would be able to stabilize the external debt-to-GDP ratio well below the relevant warning threshold. ${ }^{15}$ 


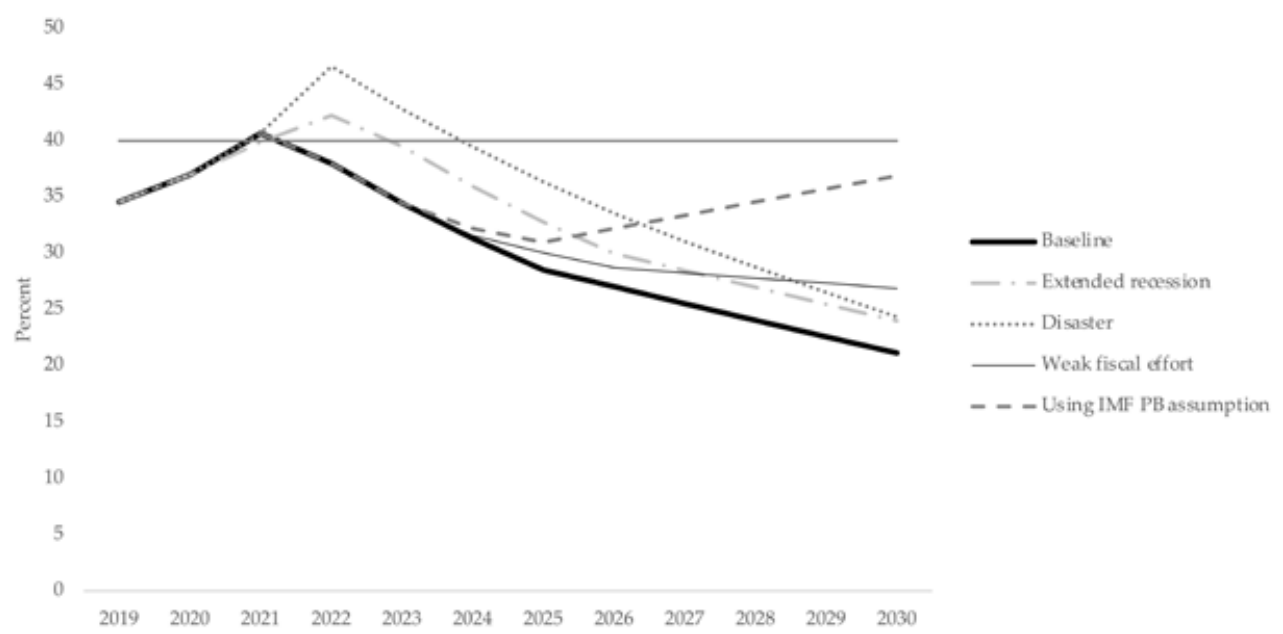

Note: GDP = gross domestic product; IMF PB = International Monetary Fund primary balance.

Sources: Authors; IMF; Government of Tonga budget documents.

Figure 5.14 Tonga public debt - near-term risks but long-run sustainability (ratio of present value of external public debt-to-GDP under different scenarios)

\section{AIDING THE PACIFIC ECONOMIC RECOVERY}

Economic recovery will hinge first and foremost on a resolution of the global health crisis, via the widespread availability of an effective vaccine and/or treatments. It will also depend critically on the strength of the global economic recovery more broadly, particularly in key regional economies like Australia, the PRC and New Zealand as critical sources of private external income via trade, tourism, and remittances. But even as this eventual recovery occurs, economic development in the Pacific is likely to have been permanently set back as a result of the business bankruptcies, lower private investment, and reduced investment in public infrastructure and human capital that has resulted from the pandemic.

One useful way to gauge the scale of potential permanent economic damage is to compare the expected trajectory of output (or output per capita) with that expected immediately before the start of the crisis. This can give us some sense of the scale of damage that is expected, at least at the current juncture. For this purpose, we use the medium-term forecasts produced by the IMF in its World Economic Outlook databases before and after the arrival of the pandemic and combine this with the longer-term growth assumptions used by the IMF in its most recent debt sustainability analyses for each country. Doing this suggests that the IMF expects the economies of Fiji and Samoa to remain about 12 percent below their pre-pandemic trajectories while the figures for PNG and Tonga would be 8 percent and 9 percent, respectively.

Fiscal stimulus is the standard macroeconomic policy prescription for enabling a stronger recovery. Notwithstanding debate about the general efficacy of fiscal stimulus in the small island Pacific context, the reality is that this would have to be driven to a significant extent by the region's development partners if it were to happen. Most Pacific governments have 
little-to-no access to international capital markets (even during "normal" times). Tapping domestic financial institutions is also a limited prospect, in part due to underdeveloped financial systems but also because large-scale domestic financing of the budget deficit would still be likely to run into binding balance of payments constraints. The upshot is that, just as Pacific governments have been unable to finance an adequate fiscal expansion in response to the initial stages of the crisis, so too will they be unable to adequately finance the fiscal stimulus needed to recover without substantial outside help.

How large would a "recovery package" from development partners need to be? Fiscal multipliers can be used to estimate the scale of support needed. The size of the multiplier associated with such a recovery package would probably be high:

- First, multipliers tend to be much more positive during recessions or when the economy is otherwise operating well below the potential multiplier (IMF 2020c). Given the size of the pandemic shock, the multiplier effect can be expected to be much larger than normal. An interesting point of reference is that the IMF has suggested that the multiplier effect in advanced and emerging economies could be as high as 2.7 during the current crisis (Gaspar et al. 2020).

- Second, the multiplier effect can be maximized by directing recovery activities toward productive investments with high economic returns. The multiplier effects associated with public investment tend to be much stronger than other forms of stimulus, since this also generates long-term economic benefits (Izquierdo et al. 2019). Many Pacific governments have infrastructure investment pipeline plans that could help to quickly identify potential projects. ${ }^{16}$ Economic returns to maintenance and climate adaptation are also particularly large, which is especially relevant in the Pacific context where there is great need in these areas (PRIF 2013; Global Commission on Adaptation 2019).

- Third, a recovery package financed by development partners would be accompanied by significant technical support to assist with effective policy, planning, design, appraisal and implementation. This would help to alleviate issues of limited institutional capacity that studies show otherwise tend to reduce the effectiveness of stimulus in many developing countries (Miyamoto et al. 2020; Gupta et al. 2014).

- Fourth, a multiyear recovery package could further help to alleviate capacity constraints while still satisfying the principle of being "timely" from a countercyclical perspective. Implementation over several years would allow for effective upfront planning while reducing the pressure on limited local implementation capacity. This is especially important in the near term when the virus itself is still a threat internationally and travel restrictions and supply chain disruptions could therefore hamper effective implementation (Guerrieri et al. 2020). Given that economic activity is likely to be depressed for several years, a multiyear stimulus program should not greatly reduce the countercyclical benefits in terms of the expected size of the multiplier effect.

- Finally, a recovery package with substantial support from development partners could have strong effects in reducing economic uncertainty and bolstering business confidence, thereby having a much stronger effect in catalyzing greater private sector investment and spending and increasing the size of the multiplier effect (IMF 2020c).

The empirical literature on the size of fiscal multipliers specifically in small states is limited. Heavy import dependence, elevated public debt, and low institutional capacity suggest that 
ordinary (i.e., government financed) fiscal multipliers are small (to the extent they can be financed) while the presence of fixed/managed exchange rates and heavily cash-constrained households and businesses suggests the opposite. One recent IMF study focused on small states finds that the medium-term fiscal multiplier from an increase in government consumption is zero but for public investment it is $0.6-1.1$, rising to as high as 1.5 during recessions (Alichi et al. 2019). For all the reasons listed above, it seems reasonable to expect that, in the current context, a well-designed recovery package financed by development partners would be able to realize a multiplier toward the top end of this range.

To determine the size of the required Pacific recovery package, we use a multiplier of 1.0-1.5 to estimate what would be needed over a three-year period to return each of our four focus Pacific economies-Fiji, PNG, Samoa, and Tonga - to their pre-virus economic trajectories. Given differing levels of economic damage from the pandemic, each country requires a different degree of stimulus, varying in the range of 2.0-4.5 percent, depending on the size of the multiplier (Figure 5.15, left panel). These four economies have been among the most significantly affected by the pandemic shock in the Pacific, thereby requiring relatively more recovery stimulus to fully recover. Repeating the exercise for all Pacific island economies, the region as a whole yields a somewhat smaller estimate of the stimulus required of about 2.1 percent to 3.1 percent of GDP in each year or between $\$ 2.3$ billion and $\$ 3.5$ billion in total over three years in constant 2019 US dollars. With this, real output per capita would recover to its pre-COVID-19 trajectory toward the end of the decade (right panel).

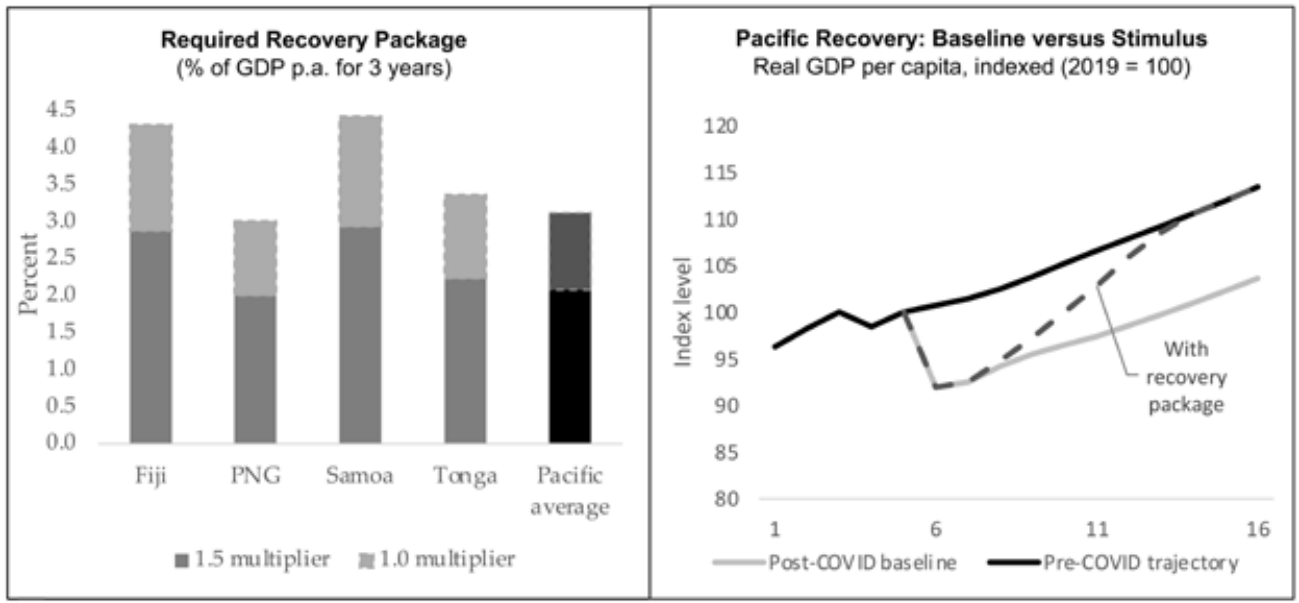

Note: $\mathrm{PNG}=$ Papua New Guinea; .a. = per annum.

Source: Authors based on IMF World Economic Outlook databases.

\section{Figure 5.15 Aiding the Pacific recovery via stimulus}

Ideally the $\$ 2.3$ billion- $\$ 3.5$ billion recovery package the Pacific needs would be financed by an increase in external grants. This would not only avoid adding to debt burdens in the Pacific but also help to improve the trajectory of public debt by raising the sustainable level of output that can be used for debt servicing. However, the odds of this occurring seem low at this point. 
Consideration must therefore be given to alternative financing options. Fortunately, a silver lining to the huge scale of the pandemic shock is that the multiplier effects are potentially large enough to make even a debt-financed recovery package a viable option.

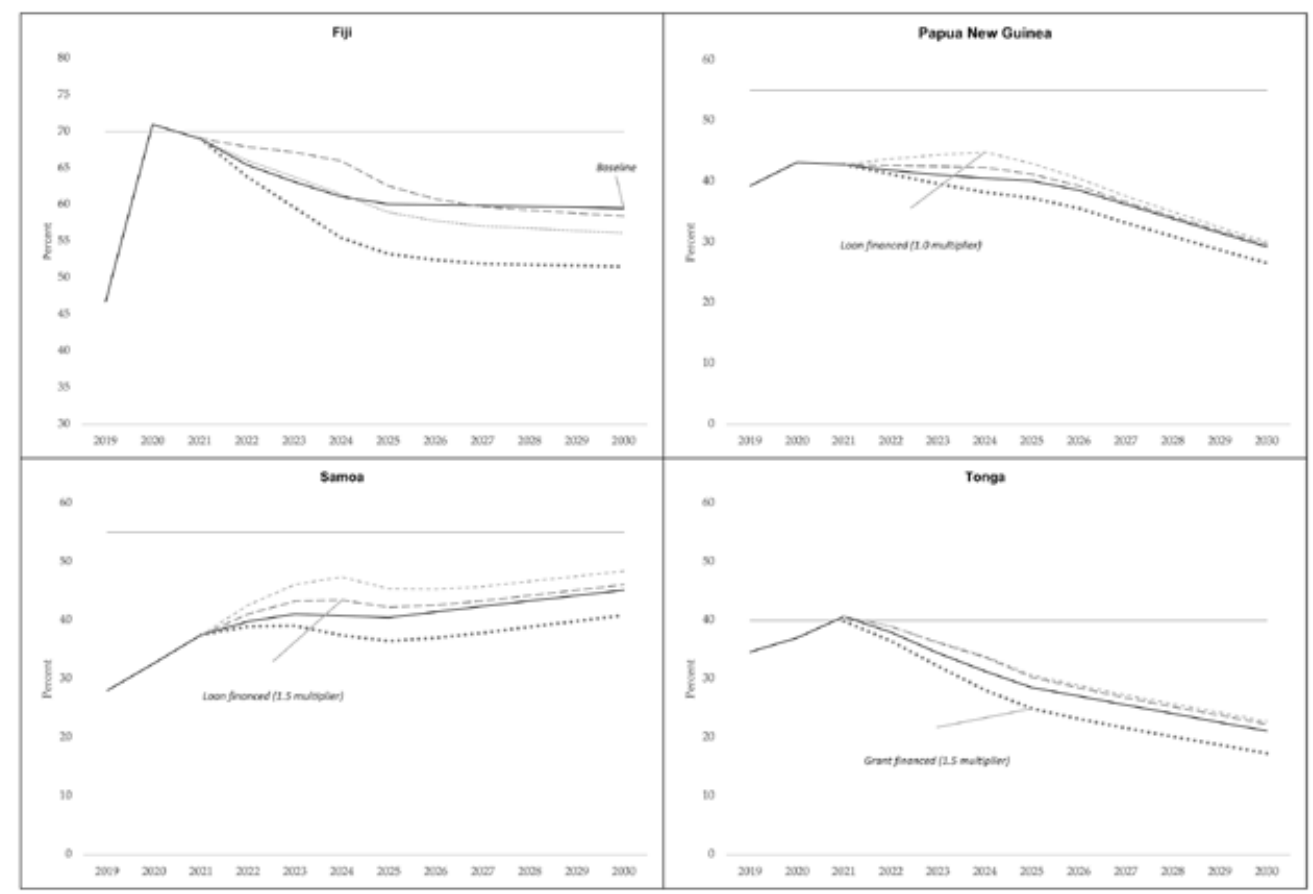

Notes:

GDP $=$ gross domestic product; $\mathrm{PNG}=$ Papua New Guinea.

* For Fiji and PNG, the figure refers to total public debt. For Samoa and Tonga, it relates to external debt since this is the more binding constraint for these economies.

Sources: Authors; IMF; government budget documents.

Figure 5.16 Impact of "recovery package" on Pacific debt sustainability (present value of key public debt-to-GDP ratio against relevant warning thresholds*)

Figure 5.16 shows the impact on our baseline for Pacific debt sustainability if the required stimulus were funded by semi-concessional loans from development partners. We assume a 2 percent interest rate, five-year grace period, and 20-year maturity-similar to the standard terms for the PRC's EXIM concessional loans as well as MDB non-concessional and Australian bilateral loans prior to the fall in global interest rates with the arrival of the virus. We show two debt-financed stimulus scenarios using a multiplier of 1 and 1.5. We also show the impact of a pure grant-financed stimulus (using a multiplier of 1.5).

Stimulus financed by semi-concessional loans is a viable option for aiding the Pacific recovery, even if grant financing would clearly be the most beneficial (Figure 5.16). Fiji is the most interesting case, with the results indicating that a recovery package financed by semi-concessional loans would actually improve its debt outlook, even using the lower multiplier of 1.0. Meanwhile in PNG, Samoa, and Tonga, debt-financed stimulus would have little material impact on long-run debt sustainability. In total, semi-concessional loans seem a viable option for reaching the scale of financing needed to aid the Pacific's economic recovery. 


\section{CONCLUSIONS}

The Pacific has been hard hit by the pandemic. Despite success in containing the domestic spread of the virus itself, the economic ramifications are likely to be severe due to the region's reliance on narrow external income sources, particularly international tourism. Debt sustainability is a perennial concern in the Pacific, owing to the region's extreme geography - giving rise to high financing needs but also a weak ability to sustainably service large amounts of public debt. Collapsing growth and pressures on government budgets due to the pandemic are substantially worsening the Pacific's debt sustainability outlook. Globally, there is significant concern about a looming debt crisis in the developing world, and international attention is focused on the need for coordinating substantial debt relief.

However, our analysis suggests that the Pacific exhibits a somewhat different set of financing challenges. The crisis is still playing out on both the health and economic fronts, so any assessment can only be preliminary and subject to high uncertainty. Nonetheless, the outlook for Pacific debt sustainability at the time of writing looks less troubling than in many other parts of the developing world, in large part reflecting the region's reliance on concessional external financing from development partners, rather than debt owed to international private creditors. Fiji's public debt situation is the most troubling, reflecting high domestic, rather than external, debt before the crisis and the devastating impact of the collapse in international tourism. Much will depend on the recovery path in tourism and how this can be balanced against the need for fiscal consolidation over the longer term to reduce debt to a safer level. In PNG, Samoa and Tonga, however, the threat to public sector solvency looks much less troubling, and the biggest problems are mostly about overcoming short-term liquidity issues.

The direct financing gaps caused by drops in government revenue are being plugged via budgetary adjustments and a combination of redirected and increased support from development partners. The true financing gap facing the Pacific, however, is the inability to mount the kind of large-scale public sector stimulus needed in order to limit the long-term economic and social damage from the pandemic. Importantly, the problems here are again more about liquidity than solvency. Our analysis shows that the $\$ 2.3$ billion- $\$ 3.5$ billion "recovery package" that we estimate is needed from development partners could be financed with semi-concessional loans without materially worsening the region's debt sustainability outlook. In Fiji, such recovery borrowing could actually improve its debt outlook over the medium term.

Of course, a large increase in external grant financing would be far more beneficial and improve the debt sustainability outlook in all countries. But this would be more costly for development partners and the odds of this occurring seem low. Other options will therefore need to be considered. Providing semi-concessional loans is one potential option and could be pursued in a variety of ways. Debt relief could form a part of this if it were specifically structured to make additional upfront financing available to help with the recovery. The key message is that unlocking greater upfront financing will be more important to the Pacific's economic recovery than simply erasing old loans or avoiding new debt.

A large development partner financed recovery package is well justified in the face of a once-in-a-century exogenous shock like COVID-19, for which concerns about moral hazard are largely irrelevant. Long-term global interest rates are also incredibly low. Pacific governments for their part will need to double-down on complementary fiscal and economic reforms that will be critical to aiding their own recoveries and making clear that enhanced development partner support at a time of mutual crisis will be money well spent. 


\section{NOTES}

1. The views expressed therein are those of the authors and do not necessarily reflect the views and policies of ADB, its Board of Governors or the governments they represent.

2. World Health Organization. Strengthening Pacific Health Systems. Accessed at: https://www.who .int/westernpacific/activities/strengthening-pacific-health-systems.

3. Development Policy Centre, Australian National University. Pacific Covid Economic Database. https://devpolicy.crawford.anu.edu.au/pacific-research-program/pacific-covid-economic-database (accessed October 2020).

4. Author's calculations based on Organisation for Economic Co-operation and Development (OECD) aid data and the World Bank data on gross national income (both available at https://data.worldbank.org/).

5. Although these ratings are produced jointly by the IMF and the World Bank, we will refer to them in this paper as IMF ratings, for brevity and as the IMF tends to lead the analysis.

6. See OECD. Official Development Assistance - Definition and Coverage. Paris. Accessed at: http:// www.oecd.org/development/financing-sustainable-development/development-finance-standards/ officialdevelopmentassistancedefinitionandcoverage.htm.

7. AidData. China's Global Development Footprint. https://www.aiddata.org/china-official-finance (accessed October 2020).

8. See the subpoint under paragraph 37 in IMF (2018) which states:

"For the World Bank (IDA) and other MDBs, regular credit terms on all lending should be assumed for all years in the projection period for which grant finance has not already been committed. These lenders link the terms of their assistance and allocation of grants to the DSF risk rating, and thus a clean assessment without possible grants is needed. Grants from these donors committed on the basis of the DSA can then be captured at the next DSA cycle."

9. At the time of writing, the Government of Fiji was seeking a rapid financing package from the IMF worth $50 \%$ of its quota (equal to a just over half a percentage point of its GDP), indicating remaining concern about Fiji's balance of payments.

10. The IMF assessment expected debt to peak at $75 \%$ of GDP in 2020 and decline to below $70 \%$ by 2025 .

11. There is also a single year breach of the external debt service-to-revenue ratio warning threshold due to a bullet payment in 2028, which is discounted by the IMF in both its current and previous assessment particularly on the back of revenues expected from future resource projects.

12. PV external debt-to-GDP ratio is expected to hover at about $22 \%$ (threshold: $40 \%$ ); external debt service to stay around 3.5\% of exports (threshold: $15 \%$ ) and around $10 \%$ of revenue (threshold: $18 \%$ ); while the PV overall debt-to-GDP ratio is expected to peak at $44 \%$ in 2024 (threshold is 55\%) and decline thereafter.

13. See IMF (2017) Debt Sustainability Analysis for Samoa for a detailed explanation of the basis for this adjustment. The IMF also incorporates a 1.3 percentage point reduction in long-term growth, which we also include in our projections. Note: both our and the IMF analyses do not include these adjustments in the "severe disaster triggered by natural hazards" scenario, since this would be double-counting the impact.

14. In the disaster scenario, the debt ratio declines in the long term below the other scenarios as it does not include the average disaster effects assumed in the baseline as per the IMF approach. Otherwise, it would double count the disaster effects.

15. For weak fiscal effort, we assume that the primary balance follows the average over the past decade at $0.8 \%$ of GDP, rather than the 20 -year average of $2.2 \%$, with a further 1 percentage point of GDP subtracted for disaster costs from 2027 onward.

16. Pacific Region Infrastructure Facility. National Infrastructure Investment Plans. https://www .theprif.org/national-infrastructure-investment-plans-niips (accessed October 2020).

\section{REFERENCES}

Alichi, A., I. Shibata and K. Tanyeri. 2019. Fiscal Policy Multipliers in Small States. IMF Working Paper. No. 19/72. Washington, DC: International Monetary Fund (IMF).

Asian Development Bank (ADB). 2017. Meeting Asia's Infrastructure Needs. Manila.

Asian Development Bank (ADB). 2018a. Key Indicators for Asia and the Pacific 2018. Manila.

Asian Development Bank (ADB). 2018b. Pacific Economic Monitor - December 2018. Manila.

Asian Development Bank (ADB). 2019. Asian Development Outlook 2019: Strengthening Disaster Resilience. Manila.

Asian Development Bank (ADB). 2020. Asian Development Outlook 2020 Update: Wellness in Worrying Times. Manila. 
Australian National University, Development Policy Centre. 2021. Pacific Covid Economic Database. Accessed at: https://devpolicy.crawford.anu.edu.au/pacific-research-program/pacific-covid-economic-database.

Bulow, J., C. Reinhart, K. Rogoff and C. Trebesch. 2020. The Debt Pandemic. International Monetary Fund Finance and Development. October. Washington, DC: IMF.

Gaspar, V., Lim, R. and M. Raissi. 2020. Public Investment for the Recovery. IMF Blog. Washington, DC: IMF.

Gibson, J. and K.L. Nero. 2007. Are Pacific Island Economies Growth Failures? Geo-Political Assessments and Perspectives. New Zealand: University of Waikato.

Global Commission on Adaptation. 2019. Adapt Now: A Global Call for Leadership on Climate Resilience. Washington, DC: World Resources Institute.

Government of Tonga. 2018. Post Disaster Rapid Assessment. Accessed at: https://www.gfdrr.org/sites/ default/files/publication/WB Tonga Report FA07.pdf.

Government of Vanuatu. 2015. Post-Disaster Needs Assessment. Accessed at: https://www.gfdrr.org/sites/ default/files/publication/WB_Tonga_Report_FA07.pdf.

Guerrieri, V., G. Lorenzoni, L. Straub and I. Werning. 2020. Macroeconomic Implications of COVID-19: Can Negative Supply Shocks Cause Demand Shortages?. NBER Working Paper. No. 26918. Accessed at: https://www.nber.org/papers/w26918.

Gupta, S., A. Kangur, C. Papageorgiou and A. Wane. 2014. Efficiency-Adjusted Public Capital and Growth. World Development. 57(May), pp. 164-78.

Howes, S. and S. Surandiran, 2020. Pacific Covid Economic Database. Development Policy Centre, Australian National University. July.

International Monetary Fund (IMF). 2015. Public Debt Limits in IMF-Supported Programs. Washington, DC.

International Monetary Fund (IMF). 2017. Samoa: Staff Report for the 2017 Article IV Consultation - Debt Sustainability Analysis. Washington, DC.

International Monetary Fund (IMF). 2018. Guidance Note on the Bank-Fund Debt Sustainability Framework for Low Income Countries. Policy Paper. Washington, DC. Accessed at: https://www.imf .org/en/Publications/Policy-Papers/Issues/2018/02/14/pp122617guidance-note-on-lic-dsf.

International Monetary Fund (IMF). 2020a. Pacific Islands Threatened by COVID-19. IMF News. Washington, DC. Accessed at: https://www.imf.org/en/News/Articles/2020/05/27/na-05272020-pacific -islands-threatened-by-covid-19.

International Monetary Fund (IMF). 2020b. Sovereign Debt: A Guide for Economists and Practitioners, Session 4: Debt Sustainability. Washington, DC.

International Monetary Fund (IMF). 2020c. Fiscal Monitor: Policies for the Recovery. Fiscal Monitor Reports. Washington, DC: IMF.

Izquierdo, A., R. Lama, J.P. Medina, J. Puig, D. Riera-Crichton, C. Vegh and G.J. Vuletin. 2019. Is the Public Investment Multiplier Higher in Developing Countries? An Empirical Exploration. IMF Working Paper. No. 19/289. Washington, DC: IMF.

Miyamoto, H., A. Baum, N. Gueorguiev, J. Honda and S. Walker. 2020. Growth Impact of Public Investment and the Role of Infrastructure Governance. In G. Schwartz, M. Fouad, T. Hansen and G. Verdier (eds), Well Spent: How Strong Infrastructure Governance Can End Waste in Public Investment. Washington, DC: IMF.

OECD website. Official Development Assistance - Definition and Coverage.

Pacific Region Infrastructure Facility (PRIF). 2013. Infrastructure Maintenance in the Pacific: Challenging the Build-Neglect-Rebuild Paradigm. Summary Paper. Sydney.

Pacific Region Infrastructure Facility. 2020. National Infrastructure Investment Plans, October.

Rajah, R., A. Dayant and J. Pryke. 2019. Ocean of Debt? Belt and Road and Debt Diplomacy in the Pacific. Sydney: Lowy Institute.

Republic of Fiji. 2020. Republic of Fiji: Assessment Letter for the Asian Development Bank and Asian Infrastructure Investment Bank. Accessed at: https:/www.adb.org/sites/default/files/linked-documents/ 48490-004-imf.pdf.

Rhur Universitat Bochum. 2018. World Risk Report 2018 Focus: Child Protection and Children's Rights. Berlin and Bochum: Bündnis Entwicklung Hilft and Ruhr University Bochum - Institute for International Law of Peace and Armed Conflict (IFHV).

World Bank. 2011. Discussion Note: Pacific Futures. Washington, DC. Accessed at: https://devpolicy.org/ publications/reports/Discussion\%20Note-Pacific\%20Futures-July\%202011.pdf.

World Bank. 2013. Samoa Post-Disaster Needs Assessment. Washington, DC. Accessed at: https:// openknowledge.worldbank.org/bitstream/handle/10986/15977/ACS44320ESW0wh00Box037981 2B00OUO090.pdf?sequence=1\&isAllowed=y. // World Health Organization 2020. Strengthening Pacific Health Systems. July 2020. 


\section{APPENDIX 5.1 BASIS OF KEY ASSUMPTIONS AND PROJECTIONS FOR EACH COUNTRY IN THE BASELINE SCENARIO}

Table 5A.1 Fiji

\begin{tabular}{|c|c|c|c|c|c|c|c|c|c|c|c|c|}
\hline & 2020 & 2021 & 2022 & 2023 & 2024 & 2025 & 2026 & 2027 & 2028 & 2029 & 2030 & $\begin{array}{l}\text { Sources and } \\
\text { Notes on } \\
\text { Assumptions }\end{array}$ \\
\hline $\begin{array}{l}\text { PV Debt-to-GDP } \\
\text { ratio }\end{array}$ & 71.0 & 69.1 & 65.4 & 63.2 & 61.1 & 60.1 & 60.0 & 59.9 & 59.8 & 59.7 & 59.5 & \\
\hline $\begin{array}{l}\text { Debt-to-GDP } \\
\text { ratio }\end{array}$ & 75.9 & 73.9 & 70.0 & 67.5 & 65.4 & 64.3 & 64.2 & 64.1 & 63.9 & 63.8 & 63.7 & $\begin{array}{l}\text { Initial debt } \\
\text { ratio: IMF } \\
\text { Article IV } \\
2019\end{array}$ \\
\hline Assumptions: & & & & & & & & & & & & \\
\hline $\begin{array}{l}\text { Real GDP } \\
\text { growth }\end{array}$ & -21 & 11.5 & 8.5 & 5.0 & 4.0 & 2.2 & 3.2 & 3.2 & 3.2 & 3.2 & 3.2 & $\begin{array}{l}\text { IMF WEO } \\
\text { Oct } 2020 \\
\text { (2020-25); } \\
\text { IMF Article } \\
\text { IV } 2019 \text { (long } \\
\text { term) }\end{array}$ \\
\hline $\begin{array}{l}\text { Real effective } \\
\text { interest rate }\end{array}$ & 3.5 & 3.5 & 3.5 & 3.5 & 3.5 & 3.5 & 3.5 & 3.5 & 3.5 & 3.5 & 3.5 & $\begin{array}{l}\text { IMF Article } \\
\text { IV } 2019 \\
\text { (projection } \\
\text { average) }\end{array}$ \\
\hline Primary balance & -6.5 & -13.7 & -4.0 & 0.2 & 1.4 & 1.8 & 0.3 & 0.3 & 0.3 & 0.3 & 0.3 & $\begin{array}{l}\text { IMF WEO } \\
\text { Oct 2020 } \\
(2020-25) \\
\text { then 20-year } \\
\text { historical } \\
\text { average }\end{array}$ \\
\hline $\begin{array}{l}\text { Average } \\
\text { concessionality } \\
\text { of debt (PV/FV) }\end{array}$ & 0.9 & 0.9 & 0.9 & 0.9 & 0.9 & 0.9 & 0.9 & 0.9 & 0.9 & 0.9 & 0.9 & $\begin{array}{l}\text { Average PV/ } \\
\text { FV of external } \\
\text { debt }=0.6 \\
\text { based on semi- } \\
\text { concessional } \\
\text { debt; constant } \\
\text { external debt } \\
\text { share }=26 \%\end{array}$ \\
\hline
\end{tabular}

Note: $\mathrm{FV}=$ face value; GDP = gross domestic product; IMF = International Monetary Fund; PV = present value; $\mathrm{WEO}=$ World Economic Outlook 
Table 5A.2 Papua New Guinea

\begin{tabular}{|c|c|c|c|c|c|c|c|c|c|c|c|c|}
\hline & 2020 & 2021 & 2022 & 2023 & 2024 & 2025 & 2026 & 2027 & 2028 & 2029 & 2030 & $\begin{array}{l}\text { Sources and } \\
\text { Notes on } \\
\text { Assumptions }\end{array}$ \\
\hline $\begin{array}{l}\text { PV Debt-to-GDP } \\
\text { ratio }\end{array}$ & 43.2 & 42.9 & 42.0 & 41.2 & 40.7 & 40.3 & 38.8 & 36.4 & 34.1 & 31.8 & 29.6 & \\
\hline $\begin{array}{l}\text { Debt-to-GDP } \\
\text { ratio }\end{array}$ & 44.0 & 44.9 & 44.8 & 45.2 & 45.7 & 45.7 & 44.6 & 42.3 & 40.1 & 37.8 & 35.5 & $\begin{array}{l}\text { Initial debt } \\
\text { ratio: IMF } 2020 \\
\text { DSA }\end{array}$ \\
\hline \multicolumn{13}{|l|}{ Assumptions: } \\
\hline Real GDP growth & -3.3 & 1.2 & 2.9 & 3.0 & 2.8 & 3.2 & 3.3 & 3.2 & 3.1 & 3.1 & 3.1 & $\begin{array}{l}\text { IMF WEO Oct } \\
2020(2020-25) \\
\text { then IMF } 2020 \\
\text { DSA }\end{array}$ \\
\hline $\begin{array}{l}\text { Real effective } \\
\text { interest rate }\end{array}$ & 0.1 & -3.1 & -2.1 & 0.1 & 1.1 & 0.9 & 0.7 & 0.4 & 0.2 & 0.0 & -0.3 & IMF 2020 DSA \\
\hline Primary balance & -3.7 & -2.8 & -2.1 & -1.7 & -1.2 & -1.1 & 0.0 & 1.1 & 1.1 & 1.1 & 1.1 & $\begin{array}{l}\text { IMF WEO Oct } \\
2020(2020-25) \\
\text { then IMF } 2020 \\
\text { DSA }\end{array}$ \\
\hline $\begin{array}{l}\text { Average } \\
\text { concessionality } \\
\text { of debt }(\mathrm{PV} / \mathrm{FV})\end{array}$ & 0.98 & 0.95 & 0.94 & 0.91 & 0.89 & 0.88 & 0.87 & 0.86 & 0.85 & 0.84 & 0.83 & IMF 2020 DSA \\
\hline
\end{tabular}

Note: DSA = debt sustainability analysis; FV = face value; GDP = gross domestic product; IMF = International Monetary Fund; PV = present value; WEO = World Economic Outlook. 
Table 5A.3 Samoa

\begin{tabular}{|c|c|c|c|c|c|c|c|c|c|c|c|c|}
\hline & 2020 & 2021 & 2022 & 2023 & 2024 & 2025 & 2026 & 2027 & 2028 & 2029 & 2030 & $\begin{array}{l}\text { Sources and Notes } \\
\text { on Assumptions }\end{array}$ \\
\hline $\begin{array}{l}\text { PV external } \\
\text { debt-to-GDP } \\
\text { ratio }\end{array}$ & 32.7 & 37.5 & 39.8 & 41.1 & 40.8 & 40.5 & 41.4 & 42.4 & 43.3 & 44.3 & 45.2 & \\
\hline $\begin{array}{l}\text { External } \\
\text { debt-to-GDP } \\
\text { ratio }\end{array}$ & 52.1 & 59.8 & 63.5 & 65.5 & 65.0 & 64.5 & 66.1 & 67.6 & 69.1 & 70.6 & 72.0 & \\
\hline $\begin{array}{l}\text { Total } \\
\text { debt-to-GDP } \\
\text { ratio }\end{array}$ & 63.4 & 72.7 & 77.3 & 79.7 & 79.1 & 78.5 & 80.4 & 82.3 & 84.1 & 85.9 & 87.6 & $\begin{array}{l}\text { Initial ratio: } \\
\text { IMF } 2020 \text { DSA } \\
\text { (includes certain } \\
\text { contingent } \\
\text { liabilities) }\end{array}$ \\
\hline \multicolumn{13}{|l|}{ Assumptions: } \\
\hline $\begin{array}{l}\text { Real GDP } \\
\text { growth }\end{array}$ & -5.0 & -1.5 & 2.7 & 2.2 & 2.2 & 2.2 & 0.9 & 0.9 & 0.9 & 0.9 & 0.9 & $\begin{array}{l}\text { IMF WEO Oct } \\
2020(2020-2025) \\
\text { and } 2020 \text { IMF } \\
\text { DSA }\end{array}$ \\
\hline $\begin{array}{l}\text { Real effective } \\
\text { interest rate }\end{array}$ & -1.2 & -0.8 & -0.5 & -0.8 & -1.1 & -1.1 & -1.1 & -1.1 & -1.1 & -1.1 & -1.1 & IMF 2020 DSA \\
\hline Primary balance & -6.5 & -8.9 & -6.8 & -4.7 & -2.0 & -2.0 & -3.5 & -3.5 & -3.5 & -3.5 & -3.5 & $\begin{array}{l}\text { IMF WEO Oct } \\
2020 \text { (2020-2025); } \\
\text { Other years: IMF } \\
\text { WEO Oct } 2019 \\
\text { (20-year historical } \\
\text { average) less } \\
\text { 1.5pp of GDP for } \\
\text { disasters from } \\
2027 \text { onwards }\end{array}$ \\
\hline $\begin{array}{l}\text { External debt } \\
\text { share }\end{array}$ & 0.8 & 0.8 & 0.8 & 0.8 & 0.8 & 0.8 & 0.8 & 0.8 & 0.8 & 0.8 & 0.8 & $\begin{array}{l}\text { Constant } 2020 \\
\text { ratio: IMF } 2020 \\
\text { DSA }\end{array}$ \\
\hline $\begin{array}{l}\text { Average } \\
\text { concessionality } \\
\text { of external debt } \\
(\mathrm{PV} / \mathrm{FV})\end{array}$ & 0.6 & 0.6 & 0.6 & 0.6 & 0.6 & 0.6 & 0.6 & 0.6 & 0.6 & 0.6 & 0.6 & $\begin{array}{l}\text { Constant } 2020 \\
\text { ratio: IMF } 2020 \\
\text { DSA }\end{array}$ \\
\hline
\end{tabular}

Note: DSA = debt sustainability analysis; FV = face value; GDP = gross domestic product; IMF = International Monetary Fund; PV = present value; WEO = World Economic Outlook. 
Table 5 A.4 Tonga

\begin{tabular}{|c|c|c|c|c|c|c|c|c|c|c|c|c|}
\hline & 2020 & 2021 & 2022 & 2023 & 2024 & 2025 & 2026 & 2027 & 2028 & 2029 & 2030 & $\begin{array}{l}\text { Sources and Notes on } \\
\text { Assumptions }\end{array}$ \\
\hline $\begin{array}{l}\text { PV external } \\
\text { debt-to-GDP } \\
\text { ratio }\end{array}$ & 37.0 & 40.7 & 38.0 & 34.4 & 31.3 & 28.6 & 27.0 & 25.6 & 24.1 & 22.6 & 21.2 & $\begin{array}{l}\text { Initial ratio: Government } \\
\text { budget statement } 2021\end{array}$ \\
\hline $\begin{array}{l}\text { External } \\
\text { debt-to-GDP } \\
\text { ratio }\end{array}$ & 39.3 & 43.2 & 40.3 & 36.6 & 33.3 & 30.3 & 28.7 & 27.1 & 25.6 & 24.0 & 22.5 & $\begin{array}{l}\text { Initial ratio: Government } \\
\text { budget statement } 2021\end{array}$ \\
\hline $\begin{array}{l}\text { Total } \\
\text { debt-to-GDP } \\
\text { ratio } \\
\text { Assumptions: }\end{array}$ & 46.1 & 50.7 & 47.3 & 42.9 & 39.0 & 35.6 & 33.7 & 31.8 & 30.0 & 28.2 & 26.4 & $\begin{array}{l}\text { Initial ratio: Government } \\
\text { budget statement } 2021\end{array}$ \\
\hline $\begin{array}{l}\text { Real GDP } \\
\text { growth }\end{array}$ & -2.5 & -3.5 & 4.0 & 3.0 & 2.5 & 1.8 & 1.1 & 1.1 & 1.1 & 1.1 & 1.1 & $\begin{array}{l}\text { IMF WEO Oct } 2020 \\
\text { (2020-2025); IMF } \\
\text { Article IV } 2017 \text { (long } \\
\text { term) incl disaster } \\
\text { effects }\end{array}$ \\
\hline $\begin{array}{l}\text { Real effective } \\
\text { interest rate }\end{array}$ & 0.3 & 0.3 & 0.3 & 0.3 & 0.3 & 0.3 & 0.3 & 0.3 & 0.3 & 0.3 & 0.3 & $\begin{array}{l}\text { IMF Article IV } 2017 \\
\text { (projection average) }\end{array}$ \\
\hline Primary balance & -0.8 & -2.8 & 1.5 & 3.1 & 3.0 & 2.9 & 1.6 & 1.6 & 1.6 & 1.6 & 1.6 & $\begin{array}{l}\text { Government budget } \\
\text { (2020-2023); IMF } \\
\text { WEO Oct } 2020 \text { (20-year } \\
\text { historical average) less } 1 \\
\text { percentage point of GDP } \\
\text { for disasters; authors } \\
\text { (interim) }\end{array}$ \\
\hline $\begin{array}{l}\text { External debt } \\
\text { share }\end{array}$ & 0.9 & 0.9 & 0.9 & 0.9 & 0.9 & 0.9 & 0.9 & 0.9 & 0.9 & 0.9 & 0.9 & $\begin{array}{l}\text { Constant } 2020 \text { ratio: } \\
\text { Government budget } \\
\text { statement } 2021\end{array}$ \\
\hline $\begin{array}{l}\text { Average } \\
\text { concessionality } \\
\text { of external debt } \\
(\mathrm{PV} / \mathrm{FV})\end{array}$ & 0.9 & 0.9 & 0.9 & 0.9 & 0.9 & 0.9 & 0.9 & 0.9 & 0.9 & 0.9 & 0.9 & $\begin{array}{l}\text { Constant } 2020 \text { ratio: } \\
\text { Government budget } \\
\text { statement } 2021\end{array}$ \\
\hline
\end{tabular}

Note $:$ DSA = debt sustainability analysis; FV = face value; GDP = gross domestic product; IMF $=$ International Monetary Fund; PV = present value; WEO = World Economic Outlook. 